\title{
Governance in Dual Class Share Firms
}

\author{
Anita Anand \\ Version Post-print/accepted manuscript \\ Citation Anand, Anita, Governance in Dual Class Share Firms (January 18, \\ (published version) 2018). The Annals of Corporate Governance, Forthcoming. Available at \\ http://dx.doi.org/10.2139/ssrn.3104712
}

How to cite TSpace items

Always cite the published version, so the author(s) will receive recognition through services that track citation counts, e.g. Scopus. If you need to cite the page number of the author manuscript from TSpace because you cannot access the published version, then cite the TSpace version in addition to the published version using the permanent URI (handle) found on the record page.

This article was made openly accessible by $U$ of $T$ Faculty. Please tell us how this access benefits you. Your story matters. 


\title{
Governance in Dual Class Share Firms
}

By

\author{
Anita Anand \\ Forthcoming in the Annals of Corporate Governance
}

J.R. Kimber Chair in Investor Protection and Corporate Governance, Faculty of Law, University of Toronto cross appointed to the Rotman School of Management anita.anand@utoronto.ca. Deep thanks to Ben Alarie, Adriana Robertson, Douglas Cumming, Naizam Kanji, Joseph McCahery, Bernard Sharfman, Richard Squire, Michael Trebilcock, Geoff Wood and Albert Yoon for valuable comments on earlier versions and some of the ideas in this paper. Profound thanks to J.D. students Christopher Puskas, Davina Shivratan, Tegan Valentine, and Alvin Yau for excellent research assistance and to the Law Foundation of Ontario for funding. 


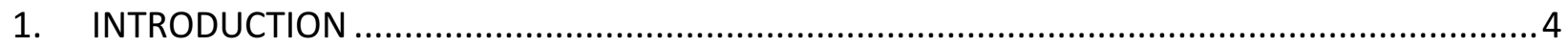

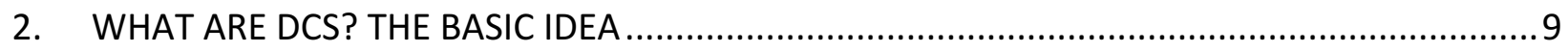

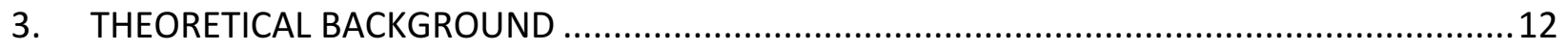

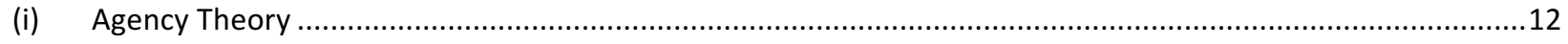

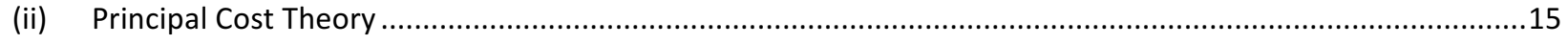

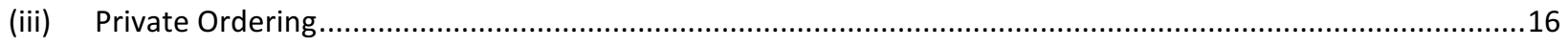

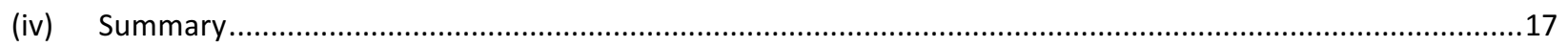

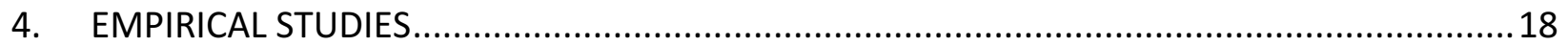

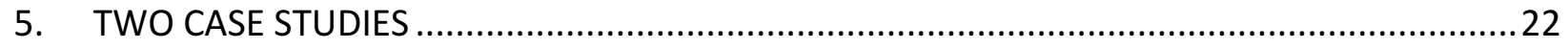

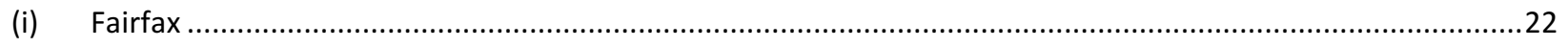

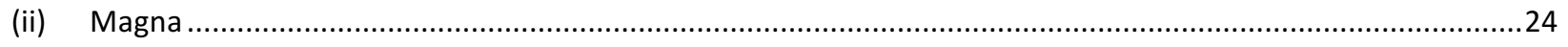

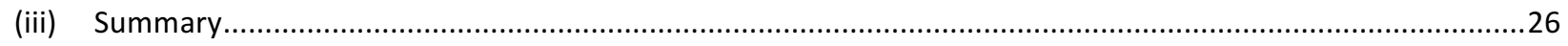

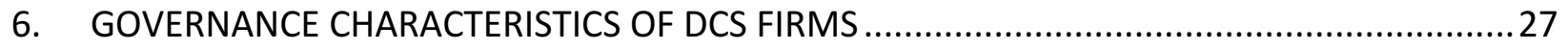

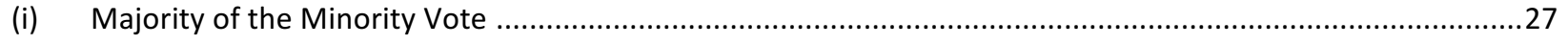

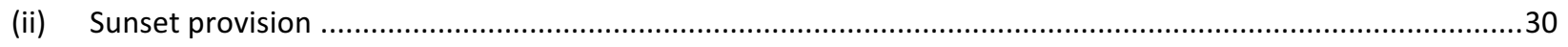

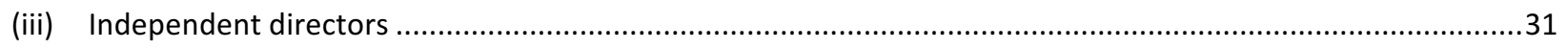

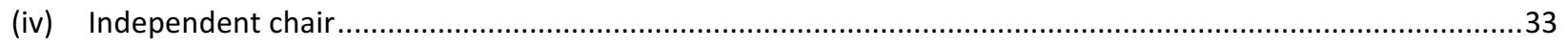

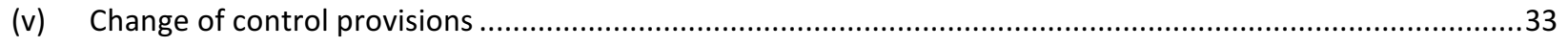

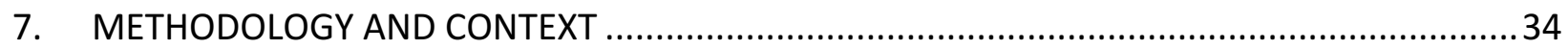

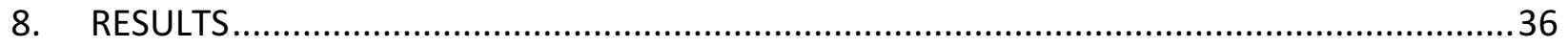

9. DIRECTIONS FOR REGULATORY REFORM .......................................................... 43

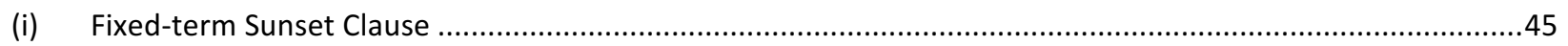

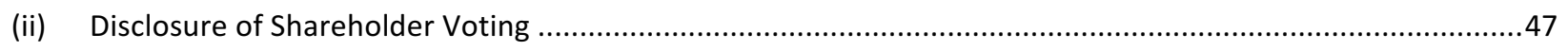

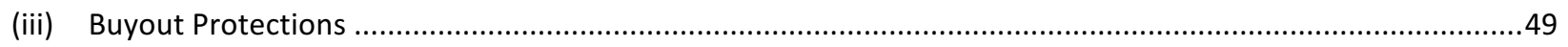

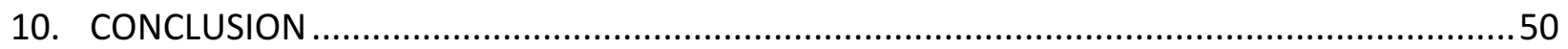




\begin{abstract}
In a typical public company, shareholders can elect the board, appoint auditors, and approve fundamental changes. Firms with dual class share structures (DCS) alter this balance by inviting the subordinate shareholders to carry the financial risk of investing in the corporation without providing them with the corresponding power to elect the board or exercise other fundamental voting rights. This article fills a conspicuous gap in the scholarly literature by providing empirical data regarding the governance of DCS firms beyond the presence of sunrise and sunset provisions. The summary data suggest that the governance of DCS firms is not uniform and DCS firms tend not to adopt governance measures voluntarily. In particular, a large proportion of DCS firms have no majority of the minority voting provisions and no independent chair. By contrast, almost half of the DCS firms have a sunset clause and a majority of independent directors. Finally, just under one-third of DCS firms have change of control provisions over and above existing law. On the basis of this evidence, the article argues against complete private ordering in favor of limited reforms to protect shareholders in DCS firms including: mandatory sunset provisions, disclosure relating to shareholder votes, and buy out protections that would address weaknesses inherent in DCS firms.
\end{abstract}




\section{Introduction}

In a typical public company, shareholders can elect the board, appoint the auditors, and approve fundamental changes. In other words, they can participate in the governance of the firm. Firms with dual class share structures (DCS) alter this balance by inviting the subordinate shareholders to carry the financial risk of investing in the firm without providing them with the corresponding power to elect the board or exercise other fundamental voting rights. As $\mathrm{Hu}$ and Black explain, DCS “decouple" voting rights and economic ownership. ${ }^{1}$

The rationale underlying DCS is that they preserve family or founder control while allowing the firm to gain access to capital in public equity markets. ${ }^{2}$ By localizing control on the founders, DCS prevent the firm from being easily acquired without the founders' cooperation. ${ }^{3}$ Indeed, DCS protect the founders from the demands of ordinary shareholders, in turn allowing them more freedom to grow the corporation. ${ }^{4}$ In the process, DCS dissuade potential suitors who would be willing to pay a premium for shares (a boon to all shareholders, except the controlling shareholder, of course). In short, DCS allow the founders to focus on long-term value creation and motivate them to make firm-specific investments in their own human capital. ${ }^{5}$

Heated controversy has arisen because DCS effectively insulate management and the board, leaving the subordinate shareholders exposed to decisions that potentially undermine their

\footnotetext{
${ }^{1}$ Henry Hu \& Bernard Black, “Equity and Debt Decoupling and Empty Voting II: Importance and Extensions" (2008) 156:3 U Pa L Rev 625.

2 Ibid.

${ }^{3}$ Tian Wen, "You can't sell your firm and own it too: disallowing dual-class stock companies from listing on the securities exchanges" (2014) 162:6 U Pa L Rev 1495, online:

<http://scholarship.law.upenn.edu/cgi/viewcontent.cgi?article=9447\&context=penn_law_review> [Wen].

4 Andrew Hill, Enrolment Open for an MBA in Murdoch, Financial Times (July 18, 2011), http://www.ft.com/cms/s/0/2fda9e8e-b176-11e0-9444-00144feab49a.html\#axzz2IYIKmzDt) as cited by Wen, ibid.

${ }^{5}$ Henrik Cronqvist \& Mattias Nilsson, "Agency Costs of Controlling Minority Shareholders", (2003) 38:4 J Fin Q A 695; Harry DeAngelo \& Linda DeAngelo, "Managerial Ownership of Voting Rights: A Study of Public Corporations with Dual Classes of Common Stock", (1985)14:1 J Fin Econ 33; Clas Bergstrom \& Kristian Rydqvist, "Ownership of Equity in Dual-Class Firms", (1990) 14:2 J Banking \& Fin 255.
} 
economic interests. ${ }^{6}$ DCS allow the firm to extract capital from subordinate shareholders without providing them with the voting power that allows them to participate in the governance of the firm. ${ }^{7}$ In short, DCS allow managers and the board to set the short-term and long-term strategy for the firm without the accountability checks provided by participation in the corporation by subordinate shareholders. $^{8}$

Some commentators argue that DCS should be permitted because otherwise, DCS firms would be left to the whims of incompetent or uninformed shareholders. ${ }^{9}$ Others argue that the weaker governance associated with DCS is built into the firm's stock price and ultimately caveat emptor should rule the day. That is, all investors have the choice as to whether to invest and “if you don't

\footnotetext{
${ }^{6}$ Anita Anand, "The success stories of dual-class shares miss an incontrovertible truth", The Globe and Mail (22 February 2016), online: <https://beta.theglobeandmail.com/report-on-business/rob-commentary/the-successstories-of-dual-class-stocks-miss-an-incontrovertible-

truth/article28830388/?ref=http://www.theglobeandmail.com\&> [Anand]; Shareholder Association for Research and Education, Second Class Investors: The Use and Abuse of Subordinate Shares in Canada (April 2004), online: <http://www.share.ca/files/Second_Class_Investors.pdf> [SHARE]; Ronald W Masulis, Cong Wang \& Fei Xie, "Agency Problems at Dual-class Companies" (2009) 64:4 J Fin 1697 [Masulis, Wang and Xie]; Milton Harris \& Artur Raviv, "Corporate Governance: Voting Rights and Majority Rules" (1988) 20:1 J Fin Econ 203 [Harris]; Wen, supra note 3.

"Andrew Willis, "Dual Class share structure should end, Caldwell Told", The Globe and Mail (5 August 2005), online: $<$ https://www.theglobeandmail.com/report-on-business/dual-class-share-structure-should-end-caldwell-

told/article18243209/>; Barry Critchley, "Time for regulators to take major look at DCS", Financial Post (14 May 2015), online: <business.financialpost.com/news/fp-street/time-for-regulators-to-take-major-look-at-dual-classshares/wcm/7b02fd1c-d28a-422c-ba39-aac77a1b6bb7>; James Surowiecki, "Unequal Shares", The New Yorker (28 May 2012), online: <www.newyorker.com/magazine/2012/05/28/unequal-shares>; Deal Professor, "Snap's Plan is Most Unfriendly to Outsiders", The New York Times (3 February 2017) online:

<https://www.nytimes.com/2017/02/03/business/dealbook/snap-ipo-plan-evan-spiegel.html>; The Economist, "Out of Control" The Economist (22 September 2014), online: <https://www.economist.com/news/finance-andeconomics/21618889-more-worlds-big-stockmarkets-are-allowing-firms-alibaba-sideline>.

${ }^{8}$ Anita Anand, "Was Magna in the Public Interest?" (2012) 49:2 Osgoode Hall L J 311.

9 Bernard S Sharfman, "A Private Ordering Defence of a Company's Right to use Dual Class Share Structures in IPOs", (2017) 63:1 Vill L Rev at 11 (forthcoming), online: <https://papers.ssrn.com/sol3/papers.cfm?abstract id=2986164> [Sharfman].
} 
like them, don't buy them. ${ }^{10}$ The opposition to DCS continues to grow with leading shareholder groups and owners of stock market indices voicing opposition to them. ${ }^{11}$

As the controversy has grown, so has the divergence of subtopics covered in empirical studies relating to DCS firms. For example, Adams and Ferreira review the empirical evidence relating to disproportionate ownership and conclude that DCS firms are not unpopular in the United Kingdom though the number of such firms is decreasing in Europe. ${ }^{12}$ In analyzing the private benefits of control across several countries, Dyck and Zingales identify transactions that involve DCS firms and measure the control premium for the holders of the superior shares (i.e. with voting power) relative to the subordinate shares (i.e. without voting power). ${ }^{13}$ They find that higher benefits of control are associated with more concentrated ownership. ${ }^{14}$ These are but two examples from the extensive literature relating to DCS which, as discussed below and in Appendix

\footnotetext{
${ }^{10}$ See Drew Hasselback \& Barbara Shecter, "From Cara Operations Itd to Shopify Inc: Why DCS are suddenly cool again", Financial Post (5 May 2015), online: <business.financialpost.com/news/fp-street/from-cara-to-google-whydual-class-shares-are-suddenly-cool-again> [Hasselback and Shecter] who quotes Carol Hansell, arguing that "if investors don't like dual-class shares, don't buy them."; See also Samer Khalil \& Michel Magnan, "Dual-Class Shares: Governance, Risk and Rewards" (May/June 2007) Ivey Business Journal Online, online: <http://iveybusinessjournal.com/publication/dual-class-shares-governance-risks-and-rewards/>; Stephen M. Bainbridge, "What To Do About Dual Class Stock (If Anything)?" (15 November 2015) Stephen Bainbridge's Journal of Law, Politics, and Culture, online:

$<$ http://www.professorbainbridge.com/professorbainbridgecom/2015/11/what-to-do-about-dual-class-stock-ifanything.html>. Bainbridge states, “Public investors who don't want lesser voting rights stock simply won't buy it. Those who are willing to purchase it presumably will be compensated by a lower per share price than full voting rights stock would command and/or by a higher dividend rate. In any event, assuming full disclosure, they become shareholders knowing that they will have lower voting rights than the insiders and having accepted as adequate whatever trade-off is offered by the firm in recompense."'; See also lan B Lee, "There is a Logic in Dual-Class Shares", National Post (8 November 2005), online: <https://www.law.utoronto.ca/documents/lee/DualClassOpEd.pdf>; Yvan Allaire, "In Praise of Dual-Class Shares" Financial Post (27 May 2015), online: <business.financialpost.com/fpcomment/in-praise-of-dual-class-of-shares>.

${ }^{11}$ See Lucian A Bebchuk \& Kobi Kastiel, "The Untenable Case for Perpetual Dual-Class Stock", online: (20 April 2017) (2017) 103:4 Va L Rev 585 at 598-599, online: <https://papers.ssrn.com/sol3/papers.cfm?abstract_id=2954630>. [Bebchuk and Kastiel] citing ISS and GMI Ratings. Also see, Ontario Securities Commission, MI 61-101 Protection of Minority Security Holders in Special Transactions and Companion Policy 61-101CP Protection of Minority Security Holders in Special Transactions (1 February 2008), online: <www.osc.gov.on.ca/documents/en/SecuritiesCategory6/rule_20080201_61-101_protect-minority.pdf> [Ontario Securities Commission].

${ }^{12}$ Daniel Ferreira \& Renee Adams, "One Share-One Vote: The Empirical Evidence" (2008) 12:1 Rev Fin 51, online: $<$ http://personal.Ise.ac.uk/FERREIRD/51.pdf>.

${ }^{13}$ These countries include Canada, Denmark, Finland, Germany, Italy, Mexico, Norway, Sweden, and the United States. See Alexander Dyck \& Luigi Zingales,"Private Benefits of Control: An International Comparison" (2004) 59:2 J Fin 537 at 593.

${ }^{14}$ Ibid.
} 
1 , suggest that DCS structures, and the academic literature relating to them, are convoluted and complex.

As a starting point and in order to provide factual context for the discussion, note that since 2008, almost 10 percent of all US firms completing IPOs have done so with a DCS in place. ${ }^{15}$ In 2015,24 percent of firms that listed their shares on US stock exchanges had DCS, compared to 15 percent of public firms in 2014 and only 1 percent in $2005 .{ }^{16}$ A number of well-known US firms, including Alphabet and Facebook, have long had DCS. In Canada, the list of DCS firms includes icons of the Canadian corporate establishment: Bombardier, Power Corp., Rogers Communications, Onex and Canadian Tire. In recent years, both countries have seen a remarkable increase in IPOs with DCS including Fitbit, Box, and a division of Alibaba in the U.S. and Cara, Aritzia, Freshii and Stingray in Canada. ${ }^{17}$ Recently stock market indices including the S\&P 500 have taken actions to exclude new listings with DCS such as Snap Inc.'s 2017 IPO. ${ }^{18}$ Needless to say, change is in the air regarding DCS.

For some jurisdictions, this debate has potentially severe consequences because DCS firms play an important role in the economy due to their substantial size relative to the average listed company. In Canada in 2015, for example, 85 out of 1487 firms listed on the Toronto Stock Exchange (TSX) - roughly $5.72 \%$ - had DCS. ${ }^{19}$ These DCS firms had an average market

\footnotetext{
${ }^{15}$ Lia Der Marderosian, “2017 IPO Report” (25 May 2017), Harvard Law School Forum on Corporate Governance and Financial Regulation (blog), online: <https://corpgov.law.harvard.edu/2017/05/25/2017-ipo-report/>.

${ }^{16}$ Spencer G Feldman, "BNA Insights: IPOs in 2016 increasingly include Dual-Class Shareholder Voting Rights", Bloomberg BNA (7 April 2016), online: <www.olshanlaw.com/media/publication/362_Feldman percent20BNA percent20Dual-Class percent20Article.pdf $>$.

${ }^{17}$ See Hasselback and Shecter, supra note 10. Also Steven Davidoff Solomon, "Shareholders Vote with Their Dollars to Have Less of a Say", New York Times (4 November 2015), online:

<https://www.nytimes.com/2015/11/05/business/dealbook/shareholders-vote-with-their-dollars-to-have-less-ofa-say.html>.

${ }^{18}$ See Fortune, "Snapchat's Stock Just Suffered a Big Setback" Fortune (1 August 2017), online: $<$ fortune.com/2017/08/01/snap-snapchat-stock-shares-sp-500/>.

19 Data taken as at Dec 31, 2015. "Listing with us", Toronto Stock Exchange (2015), online: <https://www.tsx.com/listings/listing-with-us> [Toronto Stock Exchange]; See also Matthew Merkley, "Multiple Voting Shares: Don't Call It a Comeback", (February 9, 2015) Blake, Cassels \& Graydon LLP, online: <http://www.blakes.com/English/Resources/TrendsInsights/Pages/details.aspx?AnnouncementID=78> [Merkley].
} 
capitalization of $\$ 3.39$ billion, ${ }^{20}$ while the average market capitalization of the TSX as a whole was $\$ 1.5$ billion and the median market capitalization of the TSX was a mere $\$ 111.9$ million. ${ }^{21}$ In short, DCS firms constitute a large percentage of the overall TSX Market Cap (approximately 12 percent). DCS firms constitute a big enough group to matter; this article begins with the proposition that we should carefully consider them.

A central question that arises, and which this article addresses, is the extent to which private ordering should be respected, understanding that corporate law generally upholds the choices that parties make. To what extent should the law allow the founders to pursue their "idiosyncratic vision" for the DCS corporation? ${ }^{22}$ This article undertakes a comprehensive analysis of the empirical and theoretical literature relating to DCS (which includes a complete reference chart in Appendix 1) before turning to focus on governance characteristics of DCS firms. What governance mechanisms do DCS corporations typically have? Do these governance mechanisms suggest that regulatory reform would be useful? This article argues against complete private ordering in favor of three modest reforms to improve governance in DCS firms including: mandatory fixed-term sunset provisions with a majority of the minority vote at the end of the term; disclosure relating to shareholder votes; and, buy out protections that would address weaknesses inherent in DCS firms.

At least one other academic article analyzes DCS from an empirical standpoint. Winden examines sunrise and sunset provisions found in the charters of DCS firms, with a dataset of 123 U.S. public firms. He points out, rightly, that such provisions can satisfy both the desire of entrepreneurs to pursue their idiosyncratic visions for value creation without fear of interference or dismissal and the need of investors for a voice to ensure management accountability. ${ }^{23}$

\footnotetext{
${ }^{20}$ Data obtained from Standard \& Poor's Capital IQ and supplemented by FactSet's financial database.

${ }^{21}$ Toronto Stock Exchange, supra note 19.

${ }^{22}$ Zohar Goshen \& Assaf Hamdani, “Corporate Control and Idiosyncratic Vision” (2016) (2016) 125:3 Yale L J 560, online: <https://papers.ssrn.com/sol3/papers.cfm?abstract_id=2228194>. [Goshen and Hamdani]. Sharfman, supra note 9.

${ }^{23}$ Andrew W Winden, "Sunrise, Sunset: An Empirical and Theoretical Assessment of Dual-Class Stock Structures" (2017) Rock Center for Corporate Governance at Stanford University Working Paper No. 228 <https://papers.ssrn.com/sol3/papers.cfm?abstract_id=3001574>. [Winden]
} 
Unlike Winden's study, this article examines not one but five governance characteristics of DCS firms and does so in the Canadian context where DCS have historically been more prevalent. Using a hand-collected dataset comprised of all 85 DCS firms on the Toronto Stock Exchange, it examines governance characteristics with respect to these firms that are salient in debates about DCS and governance generally. ${ }^{24}$ This article also takes a broader look at the policy implications of continuing to respect private ordering as a means for regulating public corporations.

This full-fledged examination of DCS firms comes at an opportune moment; with controversy and potential regulatory reform on the agenda, the question persists as to how and whether regulators will respond. But before reform occurs, we should know more about DCS, including DCS governance. Part 2 provides background in terms of the DCS structures and the diametrically opposed views about DCS. Part 3 examines theoretical approaches that can be used when analyzing DCS firms including agency theory and principal cost analysis. Part 4 reviews divergences of findings in the empirical literature while Part 5 takes up two case studies of transactions in which DCS firms transformed their respective governance structures. Part 6 examines five governance characteristics against which DCS firms can be examined. Part 7 outlines the methodology and context while Part 8 sets forth data regarding DCS firm governance. The empirical analysis reveals that generally speaking, DCS firms do not voluntarily adopt governance provisions over and above existing law. Part 9 focuses on policy alternatives for regulatory reform prior to the conclusion in Part 10.

\section{What are DCS? The Basic Idea}

"Dual class shares" and "multi-voting shares" are generic terms that refer to a type of capital structure in a public or private corporation. The structure involves the issuance of two or more different classes of shares whereby one class (the "superior" class) has more voting rights than

\footnotetext{
${ }^{24}$ The list draws on Anita Anand, Frank Milne \& Lynnette Purda, "Domestic and International Influences on Firmlevel governance: Evidence from Canada" (2012) 14:1 Am L \& Econ Rev 68.
} 
shares held, while the other class (the "subordinate" class) has fewer voting rights relative to the shares held. As a result, holders of the superior class of shares own a greater proportion of voting rights without having as much equity invested as the subordinate shareholders.

In a non-DCS corporation, voting rights and equity interests are aligned. This means that the ratio of votes to shares held is one to one. In other words, an individual who contributes 60 percent of the equity will typically have 60 percent company's voting rights. By contrast, in a DCS firm, the ratio is not proportional. DCS detach voting rights from the equity held, allowing an individual to retain control of a corporation without holding an equivalent financial interest in the company. The number of votes attributed to each share under these structures varies vastly from company to company.

DCS are typically implemented by founders of a corporation who wish to retain control of the company while simultaneously accessing the wealth of the public markets. ${ }^{25}$ DCS have also been used to maintain a particular level of national shareholder ownership ${ }^{26}$ and voting control. In these cases, the DCS place a limit on the proportion of total voting power which may be held by foreign investors.

Critics of DCS argue that when they are used in the public corporation context, the decoupling of voting rights and equity interests increases agency costs by allowing superior shareholders to act in self-serving ways. ${ }^{27} \mathrm{~A}$ simple example of this phenomenon is a founder's calculus on whether to purchase a luxury good. Suppose that the sole shareholder, sole director and founder of a technology start-up company travels on business and is thus interested in purchasing a luxury jet, which will depreciate in value by ten million dollars as soon as she buys it and uses it. Since she is the sole shareholder and sole director of the company, she can ultimately decide to use the

\footnotetext{
${ }^{25}$ Sharfman, supra note 9 at 6-13.

${ }^{26}$ In Canada, some companies utilise DCS structures to ensure a minimum level of Canadian ownership is maintained in accordance with applicable legislation. See discussion regarding empirical analysis infra and Appendix 4 for more on these types of DCS firms.

${ }^{27}$ Anand, supra note 6; SHARE, supra note 6; Masulis, Wang and Xie, supra note 6; Harris, supra note 6; Wen, supra note 3.
} 
corporation's profits to purchase this jet. However, she will also have to bear the full cost of her decision to make this purchase. While there is no guarantee that she will act rationally or responsibly, the alignment of voting interests and equity interests at the very least ensures that the costs of the decision will be borne by the decision maker, thus incentivizing rational, wealth maximizing behaviour.

As soon as DCS are introduced, these incentives change (or at least may change). Suppose that the corporation goes public and issues DCS such that the founder retains 60 percent of the voting rights in the company, but now with only a 10 percent equity interest in the company. The cost to the entrepreneur for the jet is now much less as the subordinate shareholders also provide capital to contribute to the cost of the jet and bear the cost of its depreciation. Suddenly, the calculation of whether to purchase the jet is significantly altered for the superior shareholder as she will be able to reap the entire benefit of the jet while bearing only a fraction of its cost and associated expenses.

This is a prototypical example of how incentives can be misaligned in a simplified DCS firm, but the decisions at issue need not relate to luxury goods or indulgent behaviour. If senior managers or board members as controlling shareholders behave in what they consider to be the best interests of the company, say by awarding large bonuses to managers who have performed well, the subordinate shareholders may nevertheless disagree that these bonuses represent an inappropriate amount for the associated performance. But the subordinate shareholders are unable to change the decision, or remove the decision makers, because they do not have the requisite voting power to affect change at the board level.

This is the key point about DCS: they create the potential, and perhaps the incentive, for directorial and managerial misbehaviour and entrenchment. ${ }^{28}$ This understanding of potential

\footnotetext{
${ }^{28}$ Blair Nicholas \& Brandon Marsh, "Dual-Class: The Consequences of Depriving Institutional Investors of Corporate Voting Rights", Harvard Law School Forum on Corporate Governance and Financial Regulation (17 May 2017), online: <https://corpgov.law.harvard.edu/2017/05/17/dual-class-the-consequences-of-depriving-institutional-investorsof-corporate-voting-rights/>. See also Lucian Bebchuk, Reinier Kraakman \& George Triantis, "Stock Pyramids, Cross-
} 
misaligned incentives is the basis for the theoretical analysis in the following section and for the

ultimate argument here that private ordering does not necessarily guarantee positive firm outcomes.

\section{Theoretical background}

The misalignment of incentives that can emerge and gain legitimacy in a DCS firm can be analyzed from different theoretical vantage points. This section addresses a few salient theoretical approaches, beginning with agency theory before turning to principal cost analysis and private ordering concepts. A complete list of studies that analyze DCS is found in Appendix 1.

\section{(i) Agency Theory}

Where do DCS sit in the context of agency theory? Scholarly research has long used agency theory to describe inherent conflicts of interest among the various stakeholders of a corporation. ${ }^{29} \mathrm{An}$ agency relationship is one in which one or more persons engages another person to perform some service on his or her behalf and which involves some delegation of decision making authority to the agent. If both parties are utility maximizers, the agent may not always act in the best interest of the principal and it is generally impossible for an agent to monitor the principal at zero cost. ${ }^{30}$

Traditionally, agency theory has been viewed as an accurate depiction of the relationship between management and shareholders in widely-held corporations rather than controlled corporations or DCS firms. In the widely-held context, the separation of ownership (shareholders)

Ownership and Dual Class Equity: The Mechanisms and Agency Costs of Separating Control From Cash-Flow Rights", (1999) The National Bureau of Economic Research Working Paper 6951, online: $<$ https://papers.ssrn.com/sol3/papers.cfm?abstract_id=147590>. [Bebchuk, Kraakman, and Triantis]

${ }^{29}$ For a summary of this research, see David Finegold, G. S Benson \& D. Hecht., "Corporate Boards and Company Performance: Review of Research in Light of Recent Reforms" (2007) 15:5 Corp Gov: Int'I Rev 865.

${ }^{30}$ Michael Jensen \& William H Meckling "Theory of the Firm: Managerial Behavior, Agency Costs and Ownership Structure" (1976) 3:4 J Fin Econ 305. [Jensen and Meckling] 
and control (management) facilitates management's ability to act in self-serving ways because individual shareholders hold a relatively small portion of the company's shares. Typical of the classic Berle and Means view of the widely-held firm, a large number of small shareholders implies that the single small shareholder has neither the power nor the incentive to devote significant resources to monitor management's behavior and undertake corrective action when appropriate. $^{31}$

The Berle and Means model is premised on the widely-held corporation as opposed to firms in which ownership is concentrated. ${ }^{32}$ However, there are various forms of ownership concentrations among large shareholders, including in DCS firms. ${ }^{33}$ Agency theory is pertinent in the DCS context because first, superior shareholders in a DCS firm can be directly or indirectly involved in managing the affairs of the corporation; and, second, conflicts of interest can be driven by the divergence of interests between large and small shareholders or between subordinate shareholders and superior shareholders in the same firm. Superior shareholders can prompt management to behave in a way consistent with their own interests at the expense of subordinate shareholders' interests.

In particular, superior shareholders are well-positioned to affect changes in firm policy which are value-increasing to them but not necessarily beneficial to the DCS firm as a whole. ${ }^{34}$ The loss

\footnotetext{
${ }^{31}$ See Jensen and Meckling, supra note 30; Andrei Shleifer \& Robert Vishny, "Large Shareholders and Corporate Control" (1986) 94:3 J Pol Econ 461. [Shleifer and Vishny]

${ }^{32}$ Adolf Berle \& Gardiner Means, The Modern Corporation and Private Property, revised ed (New York: MacMillan, 1967).

${ }^{33}$ Antonio Spizzirri \& Matt Fullbrook (2013) "The impact of family control on the share price performance of large Canadian publicly-listed firms (1998-2012)" Clarkson Centre for Board Effectiveness, online: <http://www.rotman.utoronto.ca/-/media/Files/Programs-and-Areas/CCBE/FamilyFirmPerformanceReport19932012-Sep2013update.pdf?la=en>.

${ }^{34}$ Shleifer and Vishny, supra note 31 at 472-74. For a recent example of this, see Bombardier's changes to executive compensation pay at Bombardier, Annual Meeting of Shareholders 2017 (11 May 2017), online: <http://ir.bombardier.com/en/event-calendar/68246-annual-meeting-of-shareholders-2017\#>; Allan Woods, "Bombardier's Pierre Beaudoin gives up executive title, but will continue to lead board", The Star (11 May 2017), online: <https://www.thestar.com/news/canada/2017/05/11/bombardiers-pierre-beaudoin-stepping-down-asexecutive-chair.html> [Woods]; Ross Marowitz, "Ontario Teacher's Pension Plan votes against Bombardier chair", The Star (9 May 2017), online: <https://www.thestar.com/business/2017/05/09/ontario-teachers-pension-planvotes-against-bombardier-chair.html>. Despite Bombardier receiving $\$ 372.5$ million in loans from the federal government and \$1 billion in loans from the Quebec government, Bombardier proposed to increase the pay of its
} 
resulting from these actions constitutes the archetypical "agency costs" ${ }^{35}$ including: monitoring costs borne by the principal to ensure that its agents are fulfilling their responsibilities; costs expended by the agents to provide assurance that they are doing their jobs responsibly; and the remaining loss that arises from divergent interests. ${ }^{36}$

Agency costs can arise in firms with a single class of shares and a controlling shareholder given that on any given shareholder vote, the controlling shareholder can determine the outcome (depending of course on the percentage of shares owned). ${ }^{37}$ But these firms do not raise identical concerns as DCS, since the controlling shareholder has not, undemocratically, awarded itself multiple votes per share as it has in the DCS context. ${ }^{38}$ Thus, DCS firms raise agency problems that are different in degree and kind from those that arise in the non-DCS controlling shareholder firm.

Ideally, boards of directors and senior management strive to find a balance between acting as both monitors of and advisors to the managerial team. ${ }^{39}$ This monitoring function becomes constrained in a DCS corporation since subordinate shareholders have less or no power to vote

top six executives by 50 percent. In response to widespread public backlash, Bombardier delayed salary increases but nevertheless agreed to executive pay increases despite vocal opposition from various investor rights groups. Pierre Beaudoin, who was the executive chairman at the time and remains the non-executive chairman of the board of directors, effectively controls the company through his family's multiple voting shares.

${ }^{35}$ See Jensen and Meckling, supra note 30.

${ }^{36}$ Ibid., at 308.

${ }^{37}$ Calin Valsan, "A Canadian Corporate Ownership Survey" (2007) Bishop's University - William School of Business, online: < https://papers.ssrn.com/sol3/papers.cfm?abstract_id=1158544>.

${ }^{38}$ As Ben-Amar and Andre note, a large proportion of Canadian public companies have controlling shareholders (who are typically families) who exercise voting rights disproportionate to their fraction of cash flow rights, which is often achieved through the use of DCS and stock pyramids. Walid Ben-Amar \& Paul Andre, "Separation of Ownership from Control and Acquiring Firm Performance: The Case of Family Ownership in Canada" (2006) 33:3 J of Bus Fin \& Acc 517 at 519-520 [Ben-Amar and Andre]; See also Ben Amoako-Adu \& B F Smith, "Dual Class Firms: Capitalization, Ownership Structure and Recapitalization Back into Single Class" (2001) 25:6 J Banking \& Fin 1083. Note that Anderson, Ottolenghi and Reeb point out that, at least in the U.S., the amount of economic ownership does not significantly differ between single and multi-class controlled companies. See Ronald Anderson, Ezgi Ottolenghi \& David Reeb (2017) "The Dual Class Premium: A Family Affair" Fox School of Business Research Paper No.17-021, online: <https://papers.ssrn.com/sol3/papers.cfm?abstract_id=3006669>.

${ }^{39}$ See David Anderson, Stewart Melanson \& Jiri Maly, "The Evolution of Corporate Governance: Power Redistribution Brings Boards to Life" (2007) 15:5 Corp Gov: Int'l Rev 780 at 791; Renee Adams \& Daniel Ferreira, "A Theory of Friendly Boards" (2007) 62:1 J Fin 217 at 218. 
out unaccountable or underperforming individuals; there is no built-in check on the accountability of the superior shareholders. Thus, agency costs in DCS firms can proliferate and at least differ from agency costs that arise in traditional (i.e. non DCS) corporate structures. ${ }^{40}$ DCS tie the hands of the subordinate shareholders by effectively preventing their vote from mattering.

\section{(ii) Principal Cost Theory}

While agency theory points out the way in which agency costs can arise in DCS firms, "principal cost theory" essentially functions as a defence of DCS and private ordering generally. Indeed, Goshen and Squire introduce this theory as a partial defence of DCS. ${ }^{41}$ Specifically, they argue that investors should not only be concerned with increased agency conflict costs (arising from conflicting interests between managers and investors) but also with: principal competence costs (arising from investor mistakes due to a lack of expertise); agent competence costs (arising from honest mistakes by management); and principal conflict costs (arising from conflicting interests among investors). These different costs arise on a spectrum of intensity depending on how ownership and control exist in a particular firm.

Goshen and Squire focus on the potential failings of shareholders given that shareholders are not experienced managers bound by a fiduciary duty to the corporation. But they go further and argue that the optimal arrangement of control in a particular firm is contextual i.e. firm-specific. They contend that this insight explains why empirical studies (many of which are discussed in the next section) find no consistent relationship between DCS and overall financial performance: in some firms, the structure will be value decreasing, while in others it will be value increasing. ${ }^{42}$

\footnotetext{
${ }^{40}$ Zohar Goshen \& Richard Squire, “Principal Costs: A New Theory for Corporate Law and Governance” (2017) 117:3 Colum L Rev, online: <http://columbialawreview.org/content/principal-costs-a-new-theory-for-corporate-law-andgovernance/>. [Goshen and Squire] See also Bebchuk, Kraakman, and Triantis, supra note 28.

${ }^{41}$ Goshen and Squire, supra note 40.

42 Ibid at 805-807, 815, who argue that "The use of dual-class shares structure is a good illustration of the firmspecific nature of corporate governance, as the structure may be well-suited to firms in complex industries such as information technology (e.g., Google, Facebook, and LinkedIn), or to firms whose outside shareholders recognize
} 
Consistent with this contextual view, Lin argues that DCS are useful when a company is investing primarily in intangible assets like patents or human resources, as shareholders may be more likely to misjudge the value of such long-term investments. DCS are less justified in firms with predominately tangible assets, like manufacturing or mining, since information about the value of long-term investments is more observable and verifiable to outside investors. ${ }^{43}$

\section{(iii) Private Ordering}

The idea that DCS are value-maximizing in some firms but not others has given rise to claims that favour the use of DCS. Sharfman argues that DCS facilitate efficient private ordering by allowing a company to structure its internal affairs according to its own particular qualities and attributes. ${ }^{44}$ If investors do not wish to invest in such firms, they do not need to, but the fact that IPOs with DCS are successful in attracting investments (including from sophisticated institutional investors) means that investors see the value of DCS firms in certain contexts, such as in the technology sector where the structure is commonly used. ${ }^{45}$

Claims regarding private ordering are in essence normative arguments. Goshen and Hamdani argue that entrepreneurs should be permitted to contract with investors for uncontestable control in order to pursue their idiosyncratic visions for the corporation. ${ }^{46}$ Winden contends that the DCS provides the entrepreneur with maximum ability to realize her idiosyncratic vision, which "can benefit both the entrepreneur and her investors, but as a result of the smaller equity claim

\footnotetext{
management's unique skill and strategic vision (e.g., Berkshire Hathaway). It is nonetheless an extreme option on the governance-structure menu, and it is uncommon among public firms in the United States."

${ }^{43} \mathrm{Yu}-\mathrm{H}$ sin Lin, "Controlling Controlling-minority shareholders: Corporate Governance and Leveraged Corporate Control", (2017) 2 Colum Bus L Rev 453 at 472-474, online:

< https://cblr.columbia.edu/wp-content/uploads/2017/08/1_2017.2_Lin_Final.pdf>.

${ }^{44}$ Bernard S Sharfman, "How DCS in IPOs Can Create Value", Columbia Law School's Blog on Corporations and the Capital Markets (1 August 2017), online: <http://clsbluesky.law.columbia.edu/2017/08/01/how-dual-class-sharesin-ipos-can-create-value/>

45 Ibid.

${ }^{46}$ Goshen and Hamdani, supra note 22.
} 
as compared to concentrated ownership it leaves investors with relatively high exposure to agency costs." 47 Sharfman argues that informed investors generally consider the potential risks that come with having DCS (such as increased agency costs) and weigh that against the benefits that come from having this kind of control (such as decreased principal conflict and competency costs). The optimal governance arrangement will be one that minimizes the total control costs.

Sharfman points out that in certain firms, especially those with purportedly 'visionary leaders', the optimal arrangement to minimize total costs of control may well be a DCS. There is a tradeoff: Snap Inc.'s dual class IPO received funding from sophisticated investors (many of whom had previously spoken out against non-voting shares) because investors determined that the increased potential for agency costs was offset by the reduction in principal conflict and competence costs. ${ }^{48}$ Subordinate shareholders are prepared to allow entrepreneurs maximum ability to realize their vision, which explains why this structure is in place in many major firms with founders as controlling shareholders, including: Snap (Evan Spiegel and Robert Murphy), Berkshire Hathaway (Warren Buffet), Alphabet (Larry Page and Sergey Brin), Facebook (Mark Zuckerberg), Alibaba (Jack Ma) and Comcast (Roberts family). ${ }^{49}$

\section{(iv) Summary}

These arguments favor DCS. But they are, as Bebchuk and Kastiel explain, Panglossian views. ${ }^{50}$ The arrangements that the founders adopt may not be value-maximizing at all. The DCS firms mentioned above are highly successful firms but the examples themselves are not evidence of a causal link between DCS firms and a firm that has in place a value-maximizing corporate structure. This is a key point: DCS firms may do well with such a structure but, then again, they may not. The next sections of this article are initially agnostic on this issue, and seek mainly to

\footnotetext{
${ }^{47}$ Winden, supra note 23.

${ }^{48}$ Sharfman, supra note 9 at 20 - 22. Sharfman bases his argument on Goshen and Squire's model of optimal corporate governance arrangements. See also Joseph A McCahery \& Erik P M Vermeulen, "Venture Capital 2.0: From Venturing to Partnering" 1:2 Ann Corp Gov 95, online: <http://dx.doi.org/10.1561/109.00000007> for a discussion about the decisions to implement DCS and other management entrenching takeover defence mechanisms in the context of initial financing for start-up companies.

${ }^{49}$ Sharfman, supra note 9.

${ }^{50}$ Bebchuk and Kastiel, supra note 11 at 36.
} 
provide an objective snapshot of DCS governance characteristics. The article then returns to the private ordering question, arguing that certain reforms would enhance DCS governance and accountability at least from the perspective of subordinate shareholders.

\section{Empirical Studies}

The debate between proponents and opponents of DCS is at a standstill. This standstill is due in part because the current literature is inconclusive about the relationship between DCS and firm performance. This section analyzes varying viewpoints in the empirical literature relating to DCS. A complete list of the various studies that analyze the effects of DCS on firm value is found in Appendix 1.

A number of scholars oppose DCS and have found evidence that such structures encourage managerial entrenchment and reduce shareholder wealth. Masulis, Wang and Xie, for example, find that DCS firms pay their CEOs more than non-DCS firms and are more likely to make shareholder value-destroying acquisitions. ${ }^{51}$ Hossain finds that DCS firms primarily undertake value-destroying acquisitions, while also noting that long-term post acquisition operating performance for single class firms are significantly higher than comparable DCS counterparts. ${ }^{52}$ Along similar lines, Smart and Zutter find that managers receive higher compensation in DCS firms and that these firms trade at a lower price relative to earnings and sales than their singleclass peers. $^{53}$

These studies speak to poor governance in DCS firms. On a structural level, Li and Zaiatas argue that there are general governance and transparency problems with DCS firms since they are associated with poorer information environments and increase accrual-based earning management, which is consistent with the hypothesis that managers of DCS firms are

\footnotetext{
${ }^{51}$ Masulis, Wang, and Xie, supra note 6.

${ }^{52}$ Ashrafee T Hossain, "Dual v. Single Class Firms: An Acquisition Perspective" (2014) 14:3 J Acc \& Fin 1221, online: <http://digitalcommons.www.na-businesspress.com/JAF/HossainAT_Web14_3_.pdf>.

${ }^{53}$ Scott B Smart \& Chad J Zutter, "Control as a Motivation for Underpricing: A Comparison of Dual-and Single-Class IPOs", (2003) 69:1 J Fin Econ 85, online: <http://www.sciencedirect.com/science/article/pii/S0304405X03001090>.
} 
incentivized to conceal private control benefits from outside shareholders. ${ }^{54}$ To buttress their findings, they note that after unification (i.e. after multiple classes of voting shares are collapsed into a single class of shares with equal voting rights), firms experience an improvement in the information environment and a decrease in earnings manipulation. ${ }^{55}$

Quite apart from the impact of governance changes, other studies find that, on a broad level, DCS tend to decrease firm value. Gompers, Ishii and Metric, for example, take a comprehensive view of DCS firms and find support for the hypothesis that voting control leads managers to underinvest and reduce firm value. ${ }^{56}$ King and Santor similarly note that DCS firms decrease value, as they find that family owned firms that use DCS have valuations that are lower by 17 percent on average relative to widely held firms, despite having similar return on assets and financial leverage. ${ }^{57}$ Finally, in the IPO context, Smart, Thirumalai and Zutter find that DCS firms trade at lower prices than do single class firms, both at the IPO stage and for at least five years following the IPO. They also note that general CEO turnover is sensitive to firm performance for single but not DCS firms and that, following unification, statistically and economically significant value gains occur for the company. ${ }^{58}$

With such evidence mounted against DCS firms, it may seem surprising that these firms continue to persist in our capital markets. While opponents of DCS may wish to paint the persistence of a DCS as a mix of regulatory failure and managerial self-service, the reality is that for virtually every study noting a problem with DCS firms, there is a study either finding a benefit or a neutral effect

\footnotetext{
${ }^{54}$ Ting Li \& Nataliya Zaiatas, "Information Environment and Earning Management of Dual Class Firms Around the World" (2017) 74:1 J Banking \& Fin 1, online:

$<$ http://www.sciencedirect.com/science/article/pii/S0378426616301583>

${ }^{55}$ Ibid.

${ }^{56}$ Paul A Gompers, Joy Ishii \& Andrew Metrick, "Incentives vs. Control: An Analysis of U.S. Dual-Class Companies", (2004) The National Bureau of Economic Research Working Paper 10240, online:

$<$ http://www.nber.org/papers/w10240>.

${ }^{57}$ Michael R King \& Eric Santor, "Family Values: Ownership Structure, Performance and Capital Structure of Canadian Firms" (2008) 32:11 J Banking \& Fin 2423, online:

<http://www.sciencedirect.com/science/article/pii/S0378426608000502>.

58 Scott Smart, Ramabhadran S Thirumalai \& Chad J Zutter, "What's in a vote? The Short and Long-Run Impact of Dual-Class Equity on IPO firm Values" (2008) 45:1 J Acc \& Econ 94, online:

$<$ https://kelley.iu.edu/Faculty/Finance/ssmart/publications/jae2008.pdf>.
} 
of DCS on firm value. For example, Jordan, Kim and Liu find that DCS firms face lower short term market pressures than single class firms and that DCS firms tend to have more growth opportunities (through higher sales growth and R\&D intensity). ${ }^{59}$ Similarly, Dimitrov and Jain find that DCS recapitalizations are shareholder value enhancing initiatives: on average, stockholders earned significant positive abnormal returns of 23 percent in a four year period following the announcement and this abnormal return was even larger (53 percent) for DCS firms that issued equity. $^{60}$

If they stood on their own without any contrary empirical evidence, these papers would be persuasive in pointing to the benefits of DCS firms. But just as there are studies that point to the benefits of DCS, there are corresponding studies that highlight a neutral or negative effects of DCS. Anderson, Ottolenghi and Reeb find that, after controlling for time, industry, and a wide variety of firm-specific factors, DCS alone have no effect on outside shares. ${ }^{61}$ Similarly, Ben-Amar and André find that the separation of ownership and control that accompanies DCS does not lead to value destroying $M \& A,{ }^{62}$ Gabriel Morey finds that multi-class shares have no statistically significant effect on long-term value creation, ${ }^{63}$ and Jog, Zhu, and Dutta find that restricted voting share structures do not lower firm value, operating performance, or stock performance relative to non-restrictive voting share firms. ${ }^{64}$

While neutral findings regarding DCS effects on firm performance may not seem like a persuasive reason to keep them, one must be cognizant of the fact that most proponents of DCS argue that

\footnotetext{
${ }^{59}$ Bradford Jordan, Soohyung Kim \& Mark H Liu, “Growth Opportunities, Short-Term Market Pressure, and DualClass Share Structure" (2016) 41 J Corp Fin 304, online: <https://www.sciencedirect.com/science/article/pii/S0929119916301444>.

${ }^{60}$ Valentin Dimitrov \& Prem C Jain, "Recapitalization of One Class of Common Stock into Dual-Class: Growth and Long-Run Stock Returns" (2006) 12:2 J Corp Fin 342, online: <https://www.researchgate.net/publication/223499102_Recapitalization_of_One_Class_of_Common_Stock_into_ Dual-Class_Growth_and_Long-Run_Stock_Returns>. [Dimitrov and Jain]

${ }^{61}$ Anderson, Ottolenghi and Reeb, supra note 38.

${ }^{62}$ Ben-Amar and Andre, supra note 38.

63 Gabriel Morey, "Multi-Class Stock and Firm Value", Council of Institutional Investors (May 2017), online: <http://www.cii.org/files/publications/misc/05_10_17_dual-class_value_study.pdf>.

${ }^{64}$ V M Jog, S Dutta and P C Zhu, "Impact of Restricted Voting Share Structure on Firm Value and Performance" (2010) 18:5 Corp Gov: Int'I Rev 415.
} 
firms (and investors) should be able to choose this structure if the particular company and situation warrant it, as DCS will be value-increasing in particular situations. ${ }^{65}$ For example, Nuesch finds that DCS neither harms nor benefits firm performance on average, as the effect on firm performance is context specific. In particular, DCS increase firm performance if the firm requires external financing, while hindering firm performance if the firm does not require external financing. ${ }^{66}$ This is what most DCS proponents would expect: if used in the right situation, DCS have a positive effect on firm value. Thus, the caveat emptor argument and the need for regulatory restraint are buttressed by neutral findings of DCS on firm value and performance.

While the above studies focus on the relationship between DCS and firm value, and suggest that the empirical scholarship is not determinative, more recent scholarship has turned to consider the effect of DCS on innovation. Baran, et al. show that the enhanced managerial entrenchment permitted in the DCS firm fosters innovative management culture. ${ }^{67}$ The authors study the effect of DCS on innovation, output, quality and creativity and find that disproportionate insider control is positively correlated with the number of patents and citations in a firm. Indeed, they show that high levels of innovation activity "mitigate the negative effect of excess managerial entrenchment on firm value." 68

In short, DCS may benefit young, innovate firms by engendering an innovative management culture where executives file patents more frequently. The importance of the Baran, et al. study is far-reaching: critics have warned about the increased use of DCS in the IPO context especially in the technology, media and telecommunications sectors because of governance concerns. But

\footnotetext{
${ }^{65}$ See for example Sharfman, supra note 9, and Goshen and Squire, supra note 40.

${ }^{66}$ Stephan Nuesch, "Dual-Class Shares, External Financing Needs, and Firm Performance" (2016) 20:3 J Mgmt \& Gov 525, online: <https://link.springer.com/article/10.1007/s10997-015-9313-5>.

${ }^{67}$ Lindsay Baran, Arno Forst \& M Tony Via, “Dual Class Firm Structure and Innovation” (2017) Financial Management Association (working paper), online: <http://fmaconferences.org/Boston/DualClassInnovationFMA.pdf> See also, Mark Humphery-Jenner, "Takeover Defenses, Innovation, and Value Creation: Evidence from Acquisition Decision" (2014) 35:1 Strategic Mgmt J 668 although his empirical research excludes DCS.

${ }^{68}$ Baran, et al., supra note 67 , at 5.
} 
quite apart from the counter-arguments that DCS have a positive effect on firm value, they can also have a positive effect on innovation. ${ }^{69}$

\section{Two Case Studies}

The theoretical and empirical literature spurs intense debate about DCS. This section examines two very different firms and the ways in which they have each sought to rearrange their respective DCS. The first example highlights a public corporation that seeks to retain its DCS while the second involves a public corporation that seeks to dismantle its DCS. Taken together, these two cases provide insight into the way in which a firm can adapt its DCS structure to the will of the founder and superior shareholder.

\section{(i) Fairfax}

The first example involves one of Canada's most successful firms, Fairfax Financial Inc. In 2015, Fairfax increased the ratio of multiple voting shares to subordinate voting shares from 10:1 to 50:1. This change was put to shareholders for a "majority of the minority" vote. Subordinate shareholders voted in favor of the new share structure and specifically to preserve the current 41.8 percent voting power of its founder, Chair and CEO Prem Watsa. They also voted in favor of a resolution that prevented Watsa from being able to profit, or receive any premium or benefit, from the special voting rights attached to his shares. As a result of their approval of the new structure, in the event of a change of control, subordinate shareholders also have the right to receive the same consideration on a per share basis as holders of the multiple voting shares. The new share structure also contained a five-year sunset provision; in order to continue to remain in place after 2020 , the share structure would need to be ratified by a majority of the minority vote. $^{70}$

\footnotetext{
${ }^{69}$ Baran, et al supra note 67 at 4 . See also McCahery \& Vermeulen, supra note 48 on the general use of DCS in startups under the context of maintaining innovation and entrepreneurial cultures during the lead-up to an IPO.

${ }^{70}$ Fairfax Financial Holdings, Fairfax Calls Special Shareholders' Meeting to Consider Amendment to Terms of Multiple Voting Shares (12 June 2015), online: <http://www.Fairfax.ca/news/press-releases/press-release- 
The modification to Fairfax's share terms was approved at a special meeting by $69.7 \%$ of the votes cast by subordinate shareholders. ${ }^{71}$ Prior to this final vote, the meeting to consider the proposal was postponed twice, in the first instance to "allow more time for the holders of a significant number of shares which have not been voted to vote their shares, and allow Fairfax's management to continue ongoing discussions with shareholders concerning the proposed amendment." ${ }^{\prime 2}$ The second postponement occurred because of modifications to the proposal, which Fairfax stated were "in response to discussions with certain significant institutional shareholders of Fairfax." ${ }^{73}$ With the further amendments, Fairfax garnered voting support from many of the institutional shareholders and approve the proposal. ${ }^{74}$

Fairfax wanted to undertake this transaction as insiders sought to avoid voting control that was occurring because of dilution. Thus, in the year prior to this amendment, Fairfax explored the possibility of issuing a new class of non-voting shares in order to manage dilution. However, the TSX advised that it would reject Fairfax's proposed new non-voting share class unless the class contained a coattail provision (enabling the non-voting shares to be converted into subordinate voting shares in the event of a take-over bid). ${ }^{75}$ Furthermore, a relevant securities commission

details/2015/Fairfax-Calls-Special-Shareholders-Meeting-to-Consider-Amendment-to-Terms-of-Multiple-VotingShares/default.aspx>.

${ }^{71}$ Fairfax, "Fairfax Announces Approval of Amendments to Multiple Voting Share Terms" (24 Sept 2015) , online: <http://www.fairfax.ca/news/press-releases/press-release-details/2015/Fairfax-Announces-Approval-ofAmendments-to-Multiple-Voting-Share-Terms/default.aspx>

72 Fairfax, "Fairfax Special Meeting Postponed to August 13, 2015" (20 July 2015), online: <http://www.fairfax.ca/news/press-releases/press-release-details/2015/Fairfax-Special-Meeting-Postponed-toAugust-13-2015/default.aspx>

${ }^{73}$ Fairfax, "Fairfax Announces Modifications to Multiple Voting Share Proposal and Postponement of Special Meeting of Shareholders to August 24, 2015" (11 August 2015) , online: <www.fairfax.ca/news/pressreleases/press-release-details/2015/Fairfax-Announces-Modifications-to-Multiple-Voting-Share-Proposal-andPostponement-of-Special-Meeting--of-Shareholders-to-August-24-2015/default.aspx>

74 Ibid.

${ }^{75}$ Fairfax, "Notice of Special Meeting of Shareholders", online: <https://www.sec.gov/Archives/edgar/data/915191/000104746915005451/a2225117zex-99_3.htm>. The TSX advised that the new class of shares would need a provision allow the "non-voting shares were convertible into subordinate voting shares in the event of a take-over bid for the subordinate voting shares (regardless of whether an offer was also being made for the multiple voting shares), except in circumstances where a concurrent offer on equivalent terms was also made for the non-voting shares. If holders of non-voting shares were entitled to convert their shares into subordinate voting shares and tender them to a take-over bid, such a conversion feature would create an opportunity for a third-party to make an unsolicited take-over bid for subordinate voting shares and 
rule (Rule 56-501) effectively requires shareholder approval for any recapitalization. Worried about the impact of a third-party to make a take-over bid and the corresponding conversion rights that would be triggered, Fairfax did not create a new non-voting class of shares. Instead, it proposed the amendment to its existing share structure which was ultimately approved by a majority of the minority shareholders. In this way, it was able to preserve the vision of the founder which was attractive to shareholders from a share price point of view.

\section{(ii) Magna}

Our second example involves Canada's largest auto parts manufacturer, Magna International, a multinational public corporation founded by Frank Stronach in 1957. Prior to the transaction at issue, Magna had in place a DCS with one vote per share attaching to approximately 112 million widely-held Class A subordinate voting shares and 300 votes per share attaching to approximately 700,000 Class B shares held by Stronach. The DCS enabled Stronach to maintain control of the corporation while owning a small percentage of its shares.

Under a plan of arrangement proposed in May 2010, Magna sought to collapse its DCS. The transaction, one of the largest sales of control transactions in Canadian history, involved the purchase by Magna of all Stronach's shares - constituting 0.6 percent of the equity but 66 percent of the voting rights -in exchange for 9 million subordinate voting shares totaling US $\$ 300$ million. ${ }^{76}$ The transaction diluted the holdings of the subordinate shareholders and enabled Stronach to be paid a 1,800 percent premium of the trading value of the Class B multiple voting shares.

In addition, under certain consulting contracts with the corporation, Stronach was able to receive 3 percent of Magna's pre-tax profits. Magna was required to pay the fees owing under the

\footnotetext{
potentially acquire shares representing a much larger number of votes than the $58.2 \%$ then represented by the outstanding subordinate voting shares."

${ }^{76}$ Magna International In. (Re) (2010), 34 OSC Bull 1290 at para 103 (OSC) [Full Reasons].
} 
consulting contracts for a one-year term if they were terminated early. Finally, Magna and Stronach would enter into a partnership that would be indirectly controlled by the Stronach Trust in order to develop Magna's electric vehicle business. The Magna board neither made a recommendation to shareholders nor provided them with a valuation or fairness opinion. ${ }^{77}$

In response to the proposed arrangement, staff of the relevant regulator, the Ontario Securities Commission (OSC), alleged that the transaction was contrary to the public interest for the following reasons: the circular did not contain specific financial information that the special committee of the Magna board (formed to consider the transaction) had obtained from its financial advisors; the disclosure contained neither sufficient information relating to the fairness of the transaction nor useful recommendations to shareholders; the transaction was novel and unprecedented because the shareholders were asked to approve it without a recommendation and without sufficient information; and the approval and review process was inadequate.

A group of shareholders also sought a permanent cease trade order because the transaction, in their view, was abusive and coercive. ${ }^{78}$ The OSC held that the circular did not contain sufficient disclosure and ordered more disclosure to be filed and approved before the transaction could proceed. The OSC ordered "a clear articulation"79 of how management and the board arrived at the consideration to be paid to Stronach and the potential economic benefits to shareholders. This disclosure was to include a description of the potential alternatives considered by the special committee, a discussion of the approval process adopted by the special committee, and a statement of how the financial advisors assessed the transaction, providing reasons why it could

\footnotetext{
${ }^{77}$ Ibid; See Magna International In. (Re) (2010), 33 OSC Bull 6013 [Initial Reasons]; See also Anita Anand, "Offloading the Burden of Being Public: An Analysis of Multi-Voting Share Structures", (2016) 10:3 Va L \& Bus Rev 395, online: $<$ https://papers.ssrn.com/sol3/papers.cfm?abstract_id=2728481>. [Anita Anand]

78 The "Opposing Shareholders" consisted of the Ontario Teachers' Pension Plan Board; Canada Pension Pan Investment Board; Ontario Municipal Employees Retirement System (OMERS) Administration Corporation; Alberta Investment Management Corporation; Letko, Brosseau \& Associates; and the British Columbia Investment Management Corporation. Initial Reasons, supra note 77.

${ }^{79}$ Ibid at para 41.
} 
not render a fairness opinion, among other things. ${ }^{80}$ The OSC did not issue a permanent cease trade order as staff had requested.

The terms of the transaction also required court approval and a minority shareholder vote regarding whether the transaction (being an arrangement) was "fair and reasonable." The minority shareholders approved the transaction but, as argued below, the transaction presented to them was arguably abusive since they were asked to choose between the lesser of two evils. If they voted against the transaction, they would be voting to maintain the status quo. If they voted for the transaction, they would be approving the collapse of the firm's DCS structure by paying exorbitant consideration to the founder.

\section{(iii) Summary}

In both Fairfax and Magna, there were governance changes, one in which the DCS was retained and the controlling shareholder was strengthened (Fairfax) and one in which the DCS was removed and the controlling shareholder was weakened but paid (Magna). The two scenarios illustrate the differences among DCS firms in terms of their governance. While they all by definition have some sort of multi-voting share structure, the minutiae of their governance differs. It is understandable for founders of a firm, like Watsa and Stronach, to seek to control its development via a DCS in pursuit of their respective "idiosyncratic visions." This explains why DCS have grown in popularity in recent years ${ }^{81}$ perhaps also as a response to the simultaneous rise of shareholder activism. ${ }^{82}$ As shareholders have sought to exercise their statutory rights to participate in the corporation (such as in terms of board composition), and indeed have advocated for stronger rights (such as in terms of majority voting), founders have sought to protect themselves against a loss of control. $^{83}$

\footnotetext{
${ }^{80}$ Ibid.

${ }^{81}$ See Anita Anand, supra note 77; Bebchuk and Kastiel, supra note 11.

82 Simon C Y Wong, (29 January 2013) "Rethinking One Share, One Vote" Harvard Business Review, online: <https://hbr.org/2013/01/rethinking-one-share-one-vote>.

${ }^{83}$ See for example, Onur Arugaslan, Douglas O Cook \& Robert Kieschnick, "On the Decision to go Public with Dual Class Stock" (2010) 16:2 J Corp Fin 170, online: <www.sciencedirect.com/science/article/pii/S0929119909000510>
} 


\section{Governance Characteristics of DCS Firms}

The different governance structures in the Fairfax and Magna examples discussed above invite us to look behind DCS generally to analyze governance characteristics of DCS firms. How different is the governance in DCS firms? The focus of this section is on five areas of governance characteristics chosen because of their centrality to the academic discussion (and indeed criticisms) about DCS governance: ${ }^{84}$

- whether subordinate shareholders have the ability to vote on matters (such as the way in which control is held) via a majority of the minority vote process;

- whether the DCS is subject to a sunset provision limiting the length that the DCS will persist in the corporation;

- whether the board is populated by more independent directors than is recommended by law;

- whether the board of the DCS corporation is led by an independent board chair; and

- whether the corporate charter contains provisions specifying change of control rights for the subordinate shareholders.

Each of these governance characteristics is explained below.

\section{(i) Majority of the Minority Vote}

Are subordinate shareholders provided with a majority of the minority vote (for example on the creation of the DCS, the election of directors, the appointment of auditors, or the approval of financial statements)?

who find that deviations form a one-share one vote regime are done primarily so insiders can retain control; See also Stephanie Ben-Ishai \& Poonam Puri, “Dual Class Shares in Canada: An Historical Analysis" (2006) 29:1 Dal L 117, online: $\langle$ https://papers.ssrn.com/sol3/papers.cfm?abstract_id=1427666>.

${ }^{84}$ See Anand, Milne and Purda, supra note 24. 
One of the hallmarks of corporate decision-making is the ability of shareholders to participate in the corporation by means of their vote. ${ }^{85}$ Involving shareholders in the process of developing the DCS in this way may offer a host of benefits to shareholders and the firm. Partch finds that when firms ask shareholders to approve a proposed DCS, managers are transparent as to the reasons why the firm wishes to create a second class of common stock: so that the majority shareholders can retain control while obtaining equity to finance unique growth opportunities. This is a promise with which most firms keep after the DCS is approved by a majority or super majority of shareholders. ${ }^{86}$ This transparency and dialogue with management may allow shareholders to assess the validity of the proposed business strategy and only approve the proposals that are in their interest. Dimitrov and Jain provide empirical support for this hypothesis by finding evidence that shareholders received significantly higher returns after DCS recapitalizations than their competitors. $^{87}$

Others scholars are concerned about the level of choice that shareholders exercise when approving DCS recapitalization proposals, arguing that these proposals are rarely voted down because of collective action problems. ${ }^{88}$ Individual shareholders have little incentive to do research and make an informed vote about the validity on the DCS because the costs of doing so exceed the likely returns. Thus, even if the proposal would reduce their wealth, or provide less participation in governance, individuals have little incentive to organize opposition to the

\footnotetext{
${ }^{85}$ Recognizing this, some securities regulators mandate that any reorganizing or reclassification of common voting shares into restrictive voting shares be approved by a majority of the minority shareholders. See Ontario Securities Commission, "Notice of Rule under the Securities Act Rule 56-501 Restricted Shares" (9 April 1997), online: <http://www.osc.gov.on.ca/en/SecuritiesLaw_rule_19970411_56-501_r.jsp>.

${ }^{86}$ M Megan Partch, "The Creation of a Class of Limited Voting Common Stock and Shareholder Wealth" (1987) 18:2 J Fin Econ 313 at 313-314, 317, 322, online: <www.sciencedirect.com/science/article/pii/0304405X87900432>; Richard Vecchialla, Melanie Prudom \& Robert Hamilton III, “Exposing the Corporate Vampires: A Shareholder's Guide to Management Entrenchment" (1998) 31:5 Long Range Planning 659, online:

<www.sciencedirect.com/science/article/pii/S0024630198000715>.

${ }^{87}$ Dimitrov and Jain, supra note 60.

88 Junzheng Shen, "A Comparative Analysis of Dual Class Share Structures", (4 November 2016) Columbia Law School's Blog on Corporations and the Capital Markets (blog), online:

<http://clsbluesky.law.columbia.edu/2016/11/04/a-comparative-analysis-of-dual-class-share-structures/>; Benito Arrunada \& Candido Paz-Ares, "The conversion of ordinary shares into non-voting shares" (1995) 15:4 Int' Rev L \& Econ 351, online: <www.sciencedirect.com/science/article/pii/0144818895000356>. [Arrunada and PazAres]
} 
proposal because they would bear all the costs while extracting only a fraction of the benefit. ${ }^{89}$ Arrunada and Paz-Ares argue that this creates a classic prisoner's dilemma; the individually optimal strategy is to convert one's shares into non-voting shares with higher dividends and generally accept the proposal as is, even if the collectively optimal decision for outside shareholders is not to convert their shares or accept the proposal. ${ }^{90}$

Providing voting rights to subordinate shareholders may mitigate management entrenchment that DCS create. For example, boards of directors can be effective at monitoring managers when they are independent. ${ }^{91}$ Previous studies have demonstrated that giving all shareholders the ability to nominate directors and vote in elections increases the quality of the board's independence. ${ }^{92}$ Therefore, if a DCS firm gives minority shareholders the ability to vote on board of director elections, the board is likely to be more independent than if the controlling shareholders retain all nomination and voting powers.

Given these findings, whether a DCS firm gives shareholders the opportunity to vote on important aspects of the company's governance warrants examination. Now in the Canadian context, Rule 56-501 effectively requires shareholder approval for any recapitalizations but that of course does not cover all instances in which DCS firms might act and in which subordinate shareholder voting may be warranted. The presence or absence of voting rights for minority shareholders will likely affect the opportunities afforded to management to extract private benefits from the firm, suggesting that some DCS firms may be better at protecting investor rights than others. Note, however, that there is little empirical evidence that approval by a majority of outstanding disinterested shares provides an important backstop in controlling shareholder freeze-outs,

\footnotetext{
${ }^{89}$ Arrunada and Paz-Ares, ibid.

90 Ibid.

${ }^{91}$ Cong Wang, Fei Xie \& Min Zhu, "Industry Expertise of Independent Directors and Board Monitoring" (2015) 50:5 J Fin \& Quant Analysis 929 at 929, 934, online: <https://www.cambridge.org/core/journals/journal-of-financial-andquantitative-analysis/article/industry-expertise-of-independent-directors-and-boardmonitoring/E76A14A531242C461430348A1B9DDF39>.

92 Gilberto Loureiro, “Monitoring the Board: Should Shareholders have Direct Proxy Access?" (2012) 12:6 Quant Fin 943, online:

<https://www.cambridge.org/core/journals/journal-of-financial-and-quantitative-analysis/article/industryexpertise-of-independent-directors-and-board-monitoring/E76A14A531242C461430348A1B9DDF39>.
} 
management buyouts or conflicted mergers. ${ }^{93}$ In the Israeli context, Licht suggests that such approvals are unlikely to mitigate the threat of dilution. ${ }^{94}$

\section{(ii) Sunset provision}

Is the DCS subject to a sunset provision?

As we have seen, one common argument in favour of DCS is that this structure allows founders with a corporate vision and superior leadership skills to retain control of the company, leading to benefits such as reduced agency costs and a focus on long-term growth. ${ }^{95}$ Bebchuk and Kastiel argue that a founder's potential for superior leadership decreases as the time from the IPO increases. ${ }^{96}$ Thus, a case can be made for fixed-time sunset provisions in the event a DCS is used with an IPO. ${ }^{97}$ This clause would be triggered at a predetermined date, such as ten to fifteen years after the IPO, and would automatically convert all superior voting shares into ordinary voting shares, unless extended by a majority vote of shareholders unaffiliated with the controlling shareholder. ${ }^{98}$ A "step down" mechanism is also possible e.g. 10-1 voting at IPO, 9-1 a year after and so forth.

Various organizations have also argued in favour of sunset provisions. For example, the Canadian Coalition for Good Governance, an umbrella group consisting of the country's largest institutional

\footnotetext{
93 Edward Rock, "MOM Approval in a World of Activity Investors" (2018) NYU Law and Economics Research Paper No. 18-02, online: < https://ssrn.com/abstract=3122681>.

${ }^{94}$ Amir Licht, "Be Careful What You Wish For: How Progress Engendered Regression in Related Party Transaction Regulation in Israel" (2018) European Corporate Governance Institute (ECGI) Working Paper No 382, online: <https://papers.ssrn.com/sol3/papers.cfm?abstract_id=3104062>.

${ }^{95}$ Bebchuk and Kastiel, supra note 11.

${ }^{96}$ Ibid at 1-4.

97 Ibid at 32. Other types of sunset provisions include "triggering event" sunset provisions which trigger a merging of shares upon a certain event, such as the founder's death, and "ownership-percentage" sunset provisions, which trigger conversion into regular shares when the founders have less than a certain percentage of the total number of outstanding stock. While Bebchuk and Kastiel acknowledge that these would be better than no sunset provision, they argue that these are still less preferable to fixed-term sunset provisions as they can still allow a founder to control a company for decades or even in perpetuity, one of the principle issue with DCS today that sunset provisions are designed to rectify.

${ }^{98}$ Bebchuk and Kastiel, supra note 11 at 32. Anand, supra note 6.
} 
investors, recommends that DCS remain in place for up to five years, renewable upon a majority vote by the subordinate shareholders. ${ }^{99}$ Likewise, the Council of Institutional Investors (CII) is strongly in favour of a "one share one vote rule", but argues in favour of imposing sunset provisions if a firm nevertheless issues a DCS in an IPO. ${ }^{100}$ In recent years, the CII has pushed for the S\&P Dow Jones Indices, MSCI Inc. and FTSE Russell to exclude firms with non-voting stock from their indexes unless they have sunset provisions such as a maximum sunset provision of five years (extendable with a shareholder vote to a maximum of five additional years). ${ }^{101}$

\section{(iii) Independent directors}

Does the Board comply with the suggested best practice to have a majority of directors independent?

The third DCS governance characteristics examined is whether the board has in place independent directors that exceed the amount recommended by law (which is that a majority of the Board's directors should be independent). ${ }^{102}$ Independent directors have been recognized as a key corporate governance tool to reduce agency costs by guarding against managerial

\footnotetext{
${ }^{99}$ Thomas A Fenton, "Here to stay - Dual Class Share Structures" (2016) 1:1 The Canadian Institute's Securities Law \& Litigation, online: <www.airdberlis.com/Templates/Articles/binaryServer.ashx?bin=1000721.pdf>.

${ }^{100}$ Ken Bertsch, "Unequal Voting rights in Common Stock" (CII Remarks to Investor Advisory Committee Council of Institutional Investors delivered at the U.S. Securities and exchange Commission, 9 March 2017) [unpublished]; "Dual-class stock", Council of Institutional Investors, online: <http://www.cii.org/dualclass_stock>.

${ }^{101}$ Council of Institutional Investors, "In re: S\&P Dow Jones Indices consultation with members of the investment community on the eligibility of non-voting share classes in S\&P DJI indices" (27 April 2017), CII, online: $<$ http://www.cii.org/files/issues_and_advocacy/correspondence/2017/20170426 percent20CIl percent20comment percent20S\&P percent20no percent20vote percent20share.pdf $>$. Bebchuk notes that firms such as Fitbit, Groupon, Kayak and Yelp have all adopted fixed term sunset provisions and of the fifty largest dual listed firms that went public between 2009 and 2015, twelve went public with a fixed-time sunset provision. Comparable data is not publically available for Canadian DCS firms; this article fills a gap in this regard. See also Daines and Klausner who state that at the inception of an IPO, provisions in a firm's charter provide little or no information to the market. Robert Daines \& Michael Klausner, "Do IPO Charters Maximize Firm Value? Antitakeover Protection in IPOs" (2001) 17:1 J L Econ \& Org 83.

102 National Instrument 58-101 recommends as best practice that a majority of directors are independent. Independent is defined as "no direct or indirect material relationship", see Disclosure of Corporate Governance Practices, OSC NI 58-101 (2005). [NI 58-101] Corporate statutes in Canada require that at least two out of three directors are "not officers or employees of the corporation or its affiliates", see Canada Business Corporations Act, RSC 1985, c C-44, s 102(2).
} 
entrenchment and self-serving behavior. ${ }^{103}$ The idea that independent directors can bring muchneeded management oversight to the operations of the board has given rise to advocates for independent boards worldwide.

Canadian guidelines initially recommended board independence (formally defined below) when the Toronto Stock Exchange adopted the recommendations of the report of the Toronto Stock Exchange committee on corporate governance in Canada (the Dey Committee) in 1995. In the U.S., stock exchanges altered their listing standards to require firms to maintain a majority of independent directors after the enactment of the Sarbanes-Oxley Act in $2002 .{ }^{104}$ Outside the North American context, international organizations (such as the OECD) and national stock exchanges in many countries such as the United Kingdom, Australia, Portugal, and Cyprus, have advocated board independence.

In the years since Sarbanes-Oxley, U.S. and Canadian corporations have experienced significant increases in board independence. ${ }^{105}$ Although this trend has been somewhat slower in other countries, the rate of adoption of requirements relating to independent boards is nevertheless

\footnotetext{
${ }^{103}$ See Toronto Stock Exchange, "Where Were The Directors? Guidelines for Improved Corporate Governance in Canada" (1994), The 'Dey' Report for Canadian context.

${ }^{104}$ Although the Sarbanes-Oxley Act was passed in 2002, it was not until 2003 that the Securities and Exchange Commission approved changes to the governance requirements of the United States' stock exchanges. SarbanesOxley Act of 2002, Pub.L. 107-204, 116 Stat. 745 (2002).

${ }^{105}$ See Vidhi Chhaochharia \& Yaniv Grinstein, "The Changing Structure of U.S. Corporate Boards: 1997-2003" (2007) 15:6 Corp Gov: Int'I Rev 1215; Sharon Lee \& Loring Carlson, "The Changing Board of Directors: Board Independence in S\&P 500 Firms" (2007) 11:1 J Org Culture Comm \& Conflict 31.
} 
becoming significant around the world. ${ }^{106}$ The question is whether DCS firms in particular have also adopted this governance mechanism. ${ }^{107}$

\section{(iv) Independent chair}

Is the Board of the DCS firm led by an independent chair?

The fourth DCS governance characteristics examined is whether the DCS board is led by an independent board chair. A study conducted by Anand, Purda and Milne ${ }^{108}$ found that firms with independent boards of directors are more likely than firms without independent boards to adopt mechanisms designed to enhance their ability to monitor firm management. ${ }^{109}$ But do DCS firms typically adopt an independent chair?

\section{(v) Change of control provisions}

Does the firm have change of control provisions in place over and above existing law?

\footnotetext{
${ }^{106}$ See Niamh Brennan \& Michael McDermott, “Alternative Perspectives on Independence of Directors" (2004) 12:3 Corp Gov: Int'I Rev 325; Lena Tsipouri \& Manolis Xanthakis, “Can Corporate Governance Be Rated? Ideas Based on the Greek Experience" (2004) 12:1 Corp Gov: Int'I Rev 16; Jay Dahya, Orlin Dimitrov \& John McConnell, "Dominant Shareholders, Corporate Boards and Corporate Value: A Cross-Country Analysis" (2008) 87:1 J Fin Econ 73 [Dahya et al]; Bernard Black, "The Corporate Governance Behaviour and Market Value of Russian Firms" (2001) 2:2 Emerging Market Rev 89, online: <https://papers.ssrn.com/sol3/papers.cfm?abstract_id=263014>; Beverly Jackling \& Shireenjit Johl, "Board Structure and Firm Performance: Evidence from India's Top Companies" (2009) 17:4 Corp Gov: Int'I Rev 492; Bernard Black, Hasung Jang \& Woochan Kim, “Does Corporate Governance Predict Firms' Market Values? Evidence from Korea" (2005) European Corporate Governance Institute Working Paper No 86/2005, online: <https://papers.ssrn.com/sol3/papers.cfm?abstract_id=311275>.

${ }^{107}$ Dahya et al., ibid moving beyond a single country analysis, Dahya et al examined the prevalence of independent boards in a cross-country study of firms from twenty-two countries and showed that the pervasiveness of adopting independent boards is truly global in nature.

108 Anita Anand, Frank Milne \& Lynnette Purda, "Monitoring to Reduce Agency Costs: Examining the Behavior of Independent and Non-Independent Boards" (2010) 33:4 Seattle UL Rev 809, online:

$<$ digitalcommons.law.seattleu.edu/cgi/viewcontent.cgi?article=1003\&context=sulr $>$. [Anand, Milne and Purda]

109 lbid at 835.
} 
The fifth and final governance characteristic is whether DCS firms have a corporate charter which contains provisions specifying change of control rights for the subordinate shareholders. In Canada, takeover bids of DCS firms must include a provision that no offer to acquire a class of controlling shares would be valid without the acquirer making a concurrent offer on the same terms to the other class of shareholders (these are called "coattail" voting rights). ${ }^{110}$ A DCS firm cannot have a takeover bid, a proxy contest or any other forced change without coattails. ${ }^{111}$ The question that then arises is whether DCS firms have implemented other provisions regarding changes of control: do they, for example, ensure that equivalent terms are offered to subordinate shareholders in the case of all changes of control? Do they have specific agreements under which the founders or superior shareholders agree not to transfer their shares at least not without approval of the board? Do they seek to ensure that a fair process occurs?

\section{Methodology and Context}

Using these governance characteristics, we now turn to our sample set of firms which includes all DCS firms listed on the TSX as of December 31, 2015. The total list of firms consists of 85 firms listed in Appendix 2. The data consist of two groups of firms, the first of which consists of 70 firms for which a DCS was implemented. The second group consists of 15 firms for which DCS were implemented because they were de facto mandatory, usually due to legislative requirements regarding the nationality of ownership of the firms and its shares. ${ }^{112}$ These DCS firms are referred to as the "required by law" or RBL firms, and are further described in Appendix 4, Exhibit 1. RBL firms implement DCS to ensure a minimum level of Canadian ownership is maintained in keeping with applicable legislation; they stipulate provisions by which shares are automatically converted between classes depending on whether the shareholder is Canadian or not. They further limit

\footnotetext{
110 In 1987, the TSX mandated that any company issuing a class of shares with superior voting rights would have to include a provision that no offer to acquire a class of controlling shares would be valid without the acquirer making a concurrent offer on the same terms to the other class of shareholders. "Restricted Securities", TSX Company Manual at s 624.

${ }^{111}$ DCS firms listed on the TSX prior to 1987 were "grandfathered." See Merkley, supra note 19.

112 Certain legislation restricts the level of ownership that can be held by foreigners. The DCS automatically converts shares between classes depending on whether the owner is Canadian or not. This allows the voting percentage of Canadian owners to always be above the legal minimum.
} 
the voting power of the non-Canadians such that the total voting rights held by non-Canadians do not exceed the limit as per legislation.

As mentioned above, as of 2015, 85 out of 1487 firms listed on the TSX - roughly 5.72 percent had DCS. ${ }^{113}$ These DCS firms had an average market capitalization of $\$ 3.39$ billion, ${ }^{114}$ while the average market capitalization of the TSX as a whole was $\$ 1.5$ billion, and the median market capitalization of the TSX was a mere $\$ 111.9$ million. ${ }^{115}$ In addition, the sector breakdown of DCS firms on the TSX is relatively unrepresentative of the sector breakdown of the TSX itself. While 17 percent of the listed issuers on the TSX were in the mining industry, ${ }^{116}$ only approximately 2 percent of the DCS firms in this database listed on the TSX were in the mining industry. ${ }^{117}$ The DCS firms specifically were overrepresented by firms in the communications and media sector (which made up 17.65 percent of the DCS firms as compared to 2 percent on the TSX), and diversified industries (which made up 38.82 percent of the DCS firms as compared to 13 percent on the TSX). Financial services, real estate and technology were also overrepresented amongst the DCS firms: 14.12 percent of DCS firms were in financial services as compared to 5 percent of the firms on the TSX, 9.41 percent were in real estate as compared to 4 percent on the TSX, and 7.06 percent were in technology as compared to 4 percent on the TSX.

589 firms listed on the TSX in 2015 were exchange-traded funds (ETFs), closed-end funds, specialpurpose acquisition firms (SPACS) and other non-traditional firms, making up 39.6 percent of the TSX. $^{118}$ These types of firms dominated the TSX IPO market in 2015, as 76 out of the 107 new listings in 2015 were ETFs \& closed-end fund IPOs, and 5 were capital pool firms (CPCs) or special-

\footnotetext{
113 Toronto Stock Exchange, supra note 19; See also Merkley, supra note 19.

114 Data obtained from Standard \& Poor's Capital IQ and supplemented by FactSet's financial database.

115 Toronto Stock Exchange, supra note 19.

116 Market Intelligence Group, MiG Report December 2015 (2015), online: <https://www.tsx.com/resource/en/1265/mi-g-report-december-2015-en.pdf>. [Market Intelligence Group] ${ }^{117}$ Based on the TSX classifications of the 85 firms in the DCS data set.

118 See TMX, "The MiG Report December 2015", online: <https://www.tsx.com/resource/en/1265/mi-g-reportdecember-2015-en.pdf> at 3. See also Jason Kirby, "Public companies in Canada are going the way of the Dodo", Maclean's (2 August 2016), online: <www.macleans.ca/economy/economicanalysis/public-companies-in-canadaare-going-the-way-of-the-dodo/>.
} 
purpose acquisition firms (SPACs). ${ }^{119}$ Such firms are relatively less represented amongst the DCS firms, as only 5 out of 85 firms (5.88 percent) were SPACs.

Nevertheless, DCS firms continue to gain prominence in Canadian markets. Most recently, in 2016 and 2017, a majority of the IPOs involved DCS firms which offered subordinate voting shares carrying one vote per share, while the founders or controlling shareholders maintained control through multiple voting shares. ${ }^{120}$ We turn now to examine the summary data with regard to the five governance characteristics of the DCS firms listed on the TSX.

\section{Results}

Majority of the Minority Vote: Of the 85 DCS firms examined, only eight firms had explicit majority of minority vote provisions (one of which was a required by law DCS company - Quebecor). Of the eight firms that had a relevant provision, seven firms allowed for the subordinate voting shares to elect a particular number of directors, voting as a separate class. Two DCS firms set out that the subordinate shareholders are entitled to vote separately as a class on the appointment of an auditor. One company (i.e. Fairfax described above) required a minority shareholder vote to sustain the substantial voting power of the majority shareholder. In addition, two firms (Brookfield Real Estate Services and Information Services Corp) had a special voting share which allows the holder to appoint a certain number of directors.

Of the remaining 75 firms, 70 had no explicit majority of minority rule and five had provisions enabling minority shareholders to vote in the case of qualifying acquisitions. However, the five provisions regarding qualifying acquisitions were required by legislation (under Multilateral Instrument 61-101), so do not indicate governance mechanisms put in place by the company over and above existing law.

\footnotetext{
119 Market Intelligence Group, supra note 116.

120 "Canadian IPOs on the Rebound in 2017" (19 July 2017), Torys LLP, online:

<https://www.torys.com/insights/publications/2017/07/canadian-ipos-on-the-rebound-in-2017>.
} 
Sunset Provision. The second governance characteristic examined was whether a company has a sunset provision which may limit the perpetuity of the DCS. In total, 41 firms (48.24 percent) had a sunset provision of some sort and the remaining 44 firms (51.76 percent) did not have a sunset provision at all. Of the 41 firms with a sunset provision, 10 were RBL firms.

DCS firms with a sunset provision predominantly provided that if control of DCS reached a particular point, the multiple voting shares would be converted into subordinate shares. 24 firms (44.44 percent of instances with a sunset provision) contained such a provision. Four firms (7.41 percent) included provisions that trigger conversion of multiple voting shares into subordinate shares in the event that a particular individual is no longer employed at the company; five firms (9.26 percent) included sunset provisions activated upon the closing of a qualifying acquisition; and 9 firms, all of which were RBL firms (16.67 percent), included sunset provisions pertaining to the nationality of shareholders (i.e. Canadian ownership must be maintained at a particular level). 12 firms (22.22 percent) had other restrictive clauses including provisions that shares cannot be transferred to anyone other than to a permitted person.

Table 1: Types of Sunset Provisions

\begin{tabular}{|l|l|l|}
\hline Sunset Provision Based on: & Number of Firms & \% of Total \\
\hline Voting Rights or Shares & 24 & $44.44 \%$ \\
\hline Employment & 4 & $7.41 \%$ \\
\hline Qualifying Acquisition & 5 & $9.26 \%$ \\
\hline Canadian/Foreign Ownership & 9 & $16.67 \%$ \\
\hline Other & 12 & $22.22 \%$ \\
\hline TOTAL & $\mathbf{5 4}$ & $\mathbf{1 0 0 . 0 0 \%}$ \\
\hline
\end{tabular}


In total, 41 firms had a sunset provision 11 of which stipulate several circumstances in which a sunset clause would be activated. ${ }^{121}$ Only one company specified a year at which the DCS would cease to exist altogether, Alimentation Couche-Tard. It set out that the DCS will dissolve on the day the 'Majority Holders' have reached the age of 65, which is 2021 . Fairfax also has a sunset clause tied to a time period, stipulating that under certain conditions, a shareholder ratification vote will be held every five years to sustain the presence of the DCS.

A comparison of RBL firms to the remaining DCS firms revealed that a substantially greater proportion of RBL firms had a sunset provision (66.67 percent of RBL firms had a sunset provision in comparison to 44.29 percent of DCS firms that did not require a DCS by law). How do we explain this difference? Perhaps the RBL firms believe that they can renew the DCS at the end of the period or that a DCS may not be perpetually required given potential changes in the governing legal landscape.

Independent Directors. The word "independent" embodies a consideration of whether a director is involved with management and factors such as whether the director was a participant in management over the past three years, has a family member involved in management, or has some other affiliation with the company. A director may be non-independent because his or her spouse is the company's CEO even though he or she is not involved with management per se. ${ }^{122}$

Out of the 85 DCS firms, 71 firms (83.53 percent) had a majority of independent directors on their board which is consistent with corporate governance comply-or-explain guidelines. Unsurprisingly the average proportion of independent board members was amongst the 100 largest TSX firms (a significant majority, 80\%, of these board members were independent in

\footnotetext{
${ }^{121}$ For example, Danier Leather stipulates that MVS will convert into SVS in the event that these shares are transferred to anyone other than to a permitted transferee and if Jeffrey Wortsman is no longer a senior officer of the company, amongst other stipulations. INSCAPE Corp. has a sunset provision triggered upon the death of Madan Bhayana. ONEX allows for the conversion of MVS into SVS at the option of founder Gerald Schwartz.

${ }^{122}$ See Audit Committees, OSC NI 52-110 (2004) [NI 52-110] and as referred to by NI 58-101 supra note 102.
} 
2016). ${ }^{123}$ An additional five firms (5.88 percent) had an equal number of independent and nonindependent directors. Nine firms (10.59 percent) did not adhere to best practice guidelines to have a majority of independent directors on the board. Table 2 below contains a breakdown of board independence amongst the DCS firms examined.

Table 2: Board Independence

\begin{tabular}{|l|l|l|}
\hline Board Independence & $\begin{array}{l}\text { Number of } \\
\text { Firms of Total }\end{array}$ & \\
\hline Less than half of the board was independent & 9 & $10.59 \%$ \\
\hline $\begin{array}{l}\text { Equal number of independent and non-independent directors } \\
\text { (50 percent of the board was independent) }\end{array}$ & 5 & $5.88 \%$ \\
\hline Majority of Independent Directors & 71 & $83.53 \%$ \\
\hline TOTAL & 85 & $100 \%$ \\
\hline
\end{tabular}

Independent Chair. Examination of the composition of the board of directors revealed that 61 firms (71.76 percent) did not have an independent chair per se. ${ }^{124}$ However, 47 firms (55.29 percent) had a chair who was uninvolved in the management of the firm.

\footnotetext{
123 "Canadian Spencer Stuart Board Index 2016 Board Trends and Practices of Leading Canadian Companies" (2016), Spencer Stuart, online: <https://www.spencerstuart.com/ /media/pdf\%20files/research\%20and\%20insight\%20 pdfs/\%20spencer-stuart-canadian-board-index-dec-2016.pdf> examined one hundred TSX listed companies with revenue of at least $\$ 1$ billion and for which Canadian residents comprised a minimum of $25 \%$ of each of their boards as of June 2016. The study found that $80 \%$ of these companies had a majority of independent directors in 2016 , based on the Canadian Securities Administrators definition of independence. It also states that the percentage of independent directors of the 100 largest TSX companies have been quite consistent since 2010; Yvan Alliare, "Controlled Companies Briefing" (2010) Canadian Institute of Chartered Accountants, online: < https://www.cpacanada.ca/-/media/site/business-and-accounting-resources/docs/controlled-companies-briefing--questions-for-directors-to-ask.pdf> refers to a 2009 Spencer Stuart report noting that $79 \%$ of directors for the largest 100 Canadian companies were independent in 2009.

${ }^{124}$ Based on the definition of "independence" set out in NI 52-110, supra note 122 and as referred to by NI 58-101, supra note 102.
} 
Table 3: Independent Chair

\begin{tabular}{|c|l|l|}
\hline Independent Chair & $\begin{array}{l}\text { Number of } \\
\text { Firms of Total }\end{array}$ & \\
\hline Independent chair & 24 & $28.24 \%$ \\
\hline Independent chair who is uninvolved in management & 24 & $28.24 \%$ \\
\hline Non-independent chair & 61 & $71.76 \%$ \\
\hline Non-independent chair who is uninvolved in management & 23 & $27.06 \%$ \\
\hline Non-independent chair who is involved in management & 38 & $44.71 \%$ \\
\hline TOTAL & 85 & $100 \%$ \\
\hline
\end{tabular}

Of the 61 firms with a non-independent chair, 35 appointed a "lead" independent director. A lead director chairs the meetings of independent directors. Indeed,

Arguably the position has now grown to a level where it can be seen as a separate, independent chairman-type role. The lead director is responsible for dealing with a wide gamut of tasks, from regulatory compliance through to performance evaluation of employees, directors and [other senior officers]. ${ }^{125}$

Change of Control. Only 25 firms (29.41 percent) had a change of control provision other than the mandated coattail provision. Of these firms, ten had agreements ${ }^{126}$ in place to ensure that equivalent terms are offered to subordinate shareholders in the case of a take-over. Five DCS firms had specific agreements under which the founder or majority shareholder agreed not to transfer its shares.

Summary. As suggested by Tables $4 \mathrm{a}$ and $4 \mathrm{~b}$ below, DCS firms generally do not voluntarily adopt governance provisions over and above existing law. A large proportion of DCS firms have no

\footnotetext{
125 "The Role of the Lead Director" (September 2014), Financier Worldwide, online: <https://www.financierworldwide.com/the-role-of-the-lead-director/\#.WaQeRLGZN-U>.

${ }^{126}$ These ten companies have explicit agreements made with the founders or majority shareholders and a trustee, stipulating that certain actions (e.g. the transfer of shares prior to the completion of a qualifying acquisition) require authorization by the trustee who acts on behalf of the holders of the [SVS]. See Appendix 4, Exhibit 2 for more details.
} 
majority of the minority voting provision, meaning that control rests with the superior voting shareholders. This is unsurprising of course, given that a main purpose of the DCS is to maintain control in the founder or related parties. In terms of sunset clauses, almost half of the DCS firms have one though a fair proportion of these firms (15 out of 75 firms or 17.65 percent) are RBL firms in which the DCS is present for statutory reasons relating to maintaining Canadian control rather than maintaining control amongst founders. Most DCS firms do not have an independent chair $^{127}$ but they do have chairs that are not involved with management. The majority of DCS firms have independent directors, which suggests that they can be understood to be a key monitoring mechanism in DCS firms. Yet it is possible for independent directors to be classified as independent even though they have had indirect connections with the firm or senior management. Finally, just under one-third of DCS firms have change of control provisions over and above existing law.

\footnotetext{
127 Anand, Milne and Purda, supra note 108. This is consistent with Anand, Milne and Purda's, supra note 24 finding that approximately 41.90 percent of TSX companies had an independent chair during the period of their study.
} 
Table 4a: Summary of DCS Governance Characteristics (All Firms)

\begin{tabular}{|l|l|l|}
\hline Governance Characteristic & DCS Firms With & DCS Firms Without \\
\hline Majority of the Minority Vote & $9.41 \%$ & $90.59 \%$ \\
\hline Sunset Provision & $48.24 \%$ & $51.76 \%$ \\
\hline Independent Directors & $83.53 \%$ & $16.47 \%{ }^{128}$ \\
\hline Independent Chair & $28.24 \%$ & $71.76 \%$ \\
\hline Change of Control & $29.41 \%$ & $70.59 \%$ \\
\hline
\end{tabular}

Table 4b: Summary of DCS Governance Characteristics (Excluding RBL Firms)

\begin{tabular}{|l|l|l|}
\hline Governance Characteristic & DCS Firms With & DCS Firms Without \\
\hline Majority of the Minority Vote & $10.00 \%$ & $90.00 \%$ \\
\hline Sunset Provision & $44.29 \%$ & $55.71 \%$ \\
\hline Independent Directors & $81.43 \%$ & $18.57 \%$ \\
\hline Independent Chair & $20.00 \%$ & $80.00 \%$ \\
\hline Change of Control & $30.00 \%$ & $70.00 \%$ \\
\hline
\end{tabular}

In summary, DCS firms (with and without RBL) tend not to have four out of five governance metrics in place which is especially true when RBL firms are excluded from the sample. Other than this broad general conclusion, there is considerable variability in the governance of DCS firms, even excluding the RBL firms from the sample. For example, Akita Drilling and Lassonde Industries both have two of the five governance characteristics, however, their governance differs greatly. Both firms have boards that are 44.44 percent independent, but the only other governance characteristic that Akita Drilling displays is that its chair is uninvolved with management, while Lassonde Industries has a sunset clause provision.

\footnotetext{
${ }^{128}$ Note that this includes DCS firms with a majority of non-independent directors, and firms with an equal number of independent and non-independent directors.
} 
This divergence in governance is not unique in the DCS firms examined. DCS firms generally shared minimal similarity in governance practices. Of the firms with a similar number of governance characteristics (three to four), there was some similarity as 15 out of 22 firms had a chair who was uninvolved with management and 19 firms had a majority of independent directors. However, the remaining criteria once again varied greatly. Less than half of the firms had a sunset clause ( 8 firms had one type of such provision and 1 firm had two types of sunset provisions), only 1 company had a majority of the minority provision (the company had only one type of such provision), 7 firms had an independent chair, 7 other firms had a lead independent director, and a different combination of 7 firms had a change of control provision.

We should not be surprised that governance among DCS firms varies greatly; this is the case with public firms generally. But the results suggest that law - even voluntary guidelines - can matter to firms' governance choices. DCS firms tend to have a majority of independent directors likely because this is a best practices rule in Canada's corporate governance legal regime. Given that governance of DCS firms varies greatly, one may question whether legal protections for subordinate shareholders are warranted. It is to this question that we now turn.

\section{Directions for Regulatory Reform}

There are good reasons to be concerned about governance in DCS firms. DCS structures insulate management and the board whose members may (or may not) act in the long-term best interests of the corporation. Insiders are subject to fewer checks on self-dealing and exercise an unfettered ability to define executive pay, bonuses and stock option plans. Defenders of DCS may argue that questions pertaining to DCS governance are irrelevant because the subordinate shareholders are not "forced" to carry the risk of weak governance: they can refuse to invest in DCS firms if they do not wish to bear the non-participatory risk inherent in these firms.

This argument ignores the relatively small size of the Canadian capital markets and the lack of options for many large institutional investors, including Canada's pension funds. The TSX's 
market capitalization of $\$ 2.284$ trillion is miniscule compared to NYSE's \$19.3 trillion market cap. Private ordering taken to its logical conclusion can severely limit investors' choices. In particular, 5.72 percent of TSX firms have DCS. ${ }^{129}$ If an investor does not want to invest in a DCS firm, its investment options are restricted. Canadian DCS firms have achieved 12 percent annualized returns over the last 10 years, a considerably higher rate than the 7.1 percent achieved by nonDCS firms. ${ }^{130}$ Some of the best market performers have been DCS firms; CCL Industries Inc., Fairfax, and Couche-Tard, all DCS firms, have outperformed their competitors by a considerable margin. ${ }^{131}$ In addition to the established market giants which are cross-listed on a US exchange, such as Bombardier and Rogers, an increasing number of Canadian firms launching IPOs have opted for DCS, such as Spin Master, Cara Operations, Shopify, Stingray Digital, Aritzia, and Freshii. ${ }^{132}$ If investors' forced choice is to abstain from investing in DCS firms, they are likely unable to participate in some of the most successful firms, putting them at a significant disadvantage in the relatively small capital market that characterizes the country.

One may argue that such unhappy investors should negotiate the "terms" of their contract prior to buying into the initial public offering when they could seek a sunset clause and other material governance protections. ${ }^{133}$ But as Daines and Klausner have shown, the "terms" of the IPO are not negotiated and in fact provide little information to the market. ${ }^{134}$ In other words, private ordering does not ensure that the subordinate shareholders' interests are protected on an ongoing basis. This is the starting point for the reform proposals below which are based on the idea that ideal circumstances do not always (usually) prevail.

\footnotetext{
${ }^{129} 85$ out of 1487 companies listed on the TSX as noted in Toronto Stock Exchange, supra note 19. See also Merkley, supra note 19.

130 Ibid.

131 Ibid.

132 Joe Castaldo, “Dual Class Shares are in fashion again - but they're still a bad idea”, Canadian Business (10 February 2017), online: <http://www.canadianbusiness.com/investing/dual-class-shares-are-in-fashion-again-but-theyrestill-a-bad-idea/>.

${ }^{133}$ Winden, supra note 23 at 52.

${ }^{134}$ Daines and Klausner, supra note 101.
} 


\section{(i) Fixed-term Sunset Clause with Mandatory Vote}

Various scholars advocate the use of sunset provisions. ${ }^{135}$ The rationale is sound: subordinate shareholders' interests may be abused when the corporation makes consistent non valuemaximizing decisions, an incumbent's performance declines or less talented individuals take control of the company. ${ }^{136}$ A sunset provision would mitigate this risk by barring perpetual DCS, unless subordinate shareholders agree to maintain the structure. The proposal here, however, is a slight variation on the proposal for a fixed term sunset provision: the sunset should be in place for a limited term unless further majority of the minority shareholder approval is obtained for the DCS.

A sunset provision should be agreeable to even the most ardent advocates of DCS. After all, if DCS allow firms to achieve long-term goals that are value-enhancing for all shareholders, superior and subordinate shareholders alike will vote to extend the DCS so the talented managers can stay in control. Thus, sunset provisions would allow firms to reap the purported benefits of a DCS while preventing the entrenchment of untalented management many years after the initial justification (and investor support) for the DCS have dissipated. (Drawing on the example above, the CEO of Fairfax, Prem Watsa, remained in place with a DCS only after a majority of the minority shareholders approved his enhanced control rights for a limited period of time).

One could argue that mandatory sunsets might be unnecessary if the development of the DCS eventually leads the DCS structure to be inefficient. The superior shareholder can then simply be bought out in a transaction in which the surplus created by the move from a less efficient structure to a more efficient structure is shared between the superior shareholder and the subordinate shareholders. In other words, as Squire argues, it seems that private ordering can

\footnotetext{
${ }^{135}$ See, for example, Bebchuk and Kastiel, supra note 11 and Winden, supra note 23.

${ }^{136}$ Thomas Chemmanur \& Yawen Jiao, "Dual Class IPOs: A Theoretical Analysis" (2012) 36: 1 J Banking \& Fin 305 at 306-307; 315, online: <www.sciencedirect.com/science/article/pii/S0378426611002214>. Richard Squire has mentioned in response to this argument that that founders may also make the mistake of selecting a single class structure when they should have selected a DCS. But this argument is unpersuasive in my view given that a single class structure does not bear the normative failings of a DCS and in particular the decoupling of equity from control in a systematic way. See Anita Anand, supra note 77.
} 
accomplish mid-course changes in a firm's governing structure, again making mandatory rules, such as a sunset, unnecessary. ${ }^{137}$

In response to this argument, one must appreciate the potential for abuse in the buyout of the founder. In the Magna transaction discussed above, for example, the transaction presented to the subordinate shareholders was arguably abusive. ${ }^{138}$ They were asked to choose between the lesser of two evils. On the one hand, if they voted against the transaction, they would be signaling their desire to maintain the status quo in which the superior shareholder and founder controlled Magna while holding 0.6 per cent of the equity. On the other hand, if they voted for the transaction, they would be approving the collapse of the firm's DCS structure and the firm's repurchase of the equity held by a founder who had historically extracted significant private benefits of control. The caveat, however, was that the total consideration to be paid for this transaction to occur was exorbitant.

The choice faced by subordinate shareholders in the Magna case suggests that the greater the private benefits that the founder extracts from a corporation with DCS shares, the higher the premium that will be paid to extricate the corporation from the founder. Indeed, the board of directors' decision to proceed with the transaction may heighten the incentive for a superior shareholder to increase its private benefits in order to extort a greater premium for the collapse of a DCS. This is the power of the despot that the founder can exert. ${ }^{139}$

A further difficulty with this argument is that the terms of the buyout, and the process by which these terms are negotiated and reached, have been poorly regulated. The 1,800 per cent premium was exorbitant in comparison to both market value and the typical price range that would be paid to eliminate a controlling shareholder. ${ }^{140}$ In the face of an astoundingly high

\footnotetext{
${ }^{137}$ Thank you to Richard Squire who raised this point in an email to me on December 27, 2017.

${ }^{138}$ I have presented a developed argument along these lines in Anand, "Was Magna in the Public Interest?", supra note 8 at 312 .

139 Ibid.

${ }^{140}$ See Ben Amaoko-Adu, Brian Smith \& Vishaal Baulkaran, "Unification of Dual-class Shares in Canada with Clinical Case on Magna International" (Paper delivered at the Capital Markets Institute Conference on Dual-class Shares, 
premium, the processes that the Magna board and special committee followed warranted close scrutiny and ultimately were inadequate. ${ }^{141}$ The special committee did not obtain a fairness opinion and valuation and the board did not make a recommendation to shareholders. Over and above the absence of these traditional safeguards, the special committee concluded that the transaction had positive benefits for Magna without assuring itself that it was positive for the subordinate shareholders. ${ }^{142}$

The question must be asked: If a board refuses to make a recommendation, and no valuation or fairness opinion is provided, how is it that the minority shareholders are to arrive at an informed opinion that underpins their position and ultimately their vote? Therefore, process becomes strikingly important at the end of the day. Magna is an extreme example of DCS buyouts gone wrong. On the positive side ex post, the transaction suggests that sunsets are a useful addition to the legal regime in addition to other reforms discussed below.

\section{(ii) Disclosure of Shareholder Voting}

Shareholder voting expresses an evaluation of the status quo irrespective of the outcome of the voting process. Shareholder dissent in cases such as proxy contests may lead to subsequent governance reforms because such votes act as a public signal of discontent with the way the firm is currently governed. Management may act on these signals even when the results are nonbinding. ${ }^{143}$

Rotman School of Management, University of Toronto 15 February 2011, [unpublished], online: <http://www.rotman.utoronto.ca/userfiles/cmi/file/Magna\%20Unif2_Feb\%207\%20(Revised).pdf>. The paper compares Stronach's percentage return to the return paid to what other companies paid their controlling shareholders who held superior voting shareholders of the 31 previous cases of unification on the TSX, only one had a special payout to the controlling shareholder similar in magnitude to the payout to Magna's founder.

${ }^{141}$ See also remarks by Justice Wilton-Siegel following the Magna transaction, in Tim Kiladze, (22 February 2011)

"Magna board 'spectacularly' vacated field: judge," The Globe and Mail, online:

<http://www.theglobeandmail.com/globe-investor/investment-ideas/streetwise/magna-board-spectacularlyvacated-field-judge/article1916419/>.

${ }^{142}$ Edward lacobucci, “Making Sense of Magna” (2011) 49:2 Osgoode Hall LJ 237 at 251.

${ }^{143}$ Steve Sauerwald, J Van Oosterhout \& Marc Van Essen, "Expressive Shareholder Democracy: A Multilevel Study of Shareholder Dissent in 15 Western European Countries" (2016) 53:4 J Mgmt Stud 520 at 524-525, online: <onlinelibrary.wiley.com/doi/10.1111/joms.12171/full>. 
For example, the United Kingdom became the first country to require that shareholders be given an advisory vote on board pay, which subsequently led to more significant dialogue between shareholders and management and tangible changes to executive pay. Specifically, after this requirement was implemented, executive compensation only rose between five to six percent in 2006, which was a sharp reduction from the average 14 percent increases in the preceding five years.

More recently, lliev, et al. conducted a study of 8160 firms across 43 countries and found that high rates of dissenting votes from outside shareholders led to higher rates of director turnover and more withdrawals from mergers and acquisitions deals. ${ }^{144}$ Their study was consistent with previous empirical research which found that high dissenting vote percentages are often followed by corporate governance changes in the following year. ${ }^{145}$

Thus, in the context of DCS firms, requiring the separation and disclosure of subordinate and controlling shareholder vote counts could put some pressure on management to change its behavior, which would be similar to how the "comply or explain" approach works by putting soft pressure on corporations to voluntarily comply with best practices recommendations. ${ }^{146}$ Without such disclosure, one cannot tell how shareholders unaffiliated with the controlling shareholder voted, potentially giving a false sense of support for the management team. By mandating disclosure of controlling and subordinate vote results separately, subordinate shareholders may be able to express their dissatisfaction with the status quo and exercise the potential disciplining effects that come from expressive voting noted above.

\footnotetext{
${ }^{144}$ Peter Iliev, K V Lins, et al, "Shareholder Voting and Corporate Governance Around the World" (2015) 28:8 Rev Fin Stud 2167 at 2192, 2196, online: <https://academic.oup.com/rfs/article/28/8/2167/1599500/Shareholder-Votingand-Corporate-Governance-Around>.

145 Ibid at 2168.

${ }^{146}$ Such a disclosure requirement may have been useful at the recent Bombardier AGM, where the management was happy to report that over 90 percent of shareholders voted to reelect the board of directors and also voted in favor of a hotly contested executive compensation package. See Marowitz, supra note 34. Regarding comply or explain generally, see Anita Anand, "An Analysis of Enabling vs Mandatory Corporate Governance: Structures PostSarbanes-Oxley" (2006) 31:1 Del J Corp L 229 and Anand, Milne and Purda, supra note 24.
} 


\section{(iii) Buyout Protections}

The Magna transaction discussed above suggests that the process under which buyouts occur are in the end substantively important to the subordinate shareholders. Ensuring that these shareholders are adequately protected in the context of the buyout of the founder is difficult to ensure prior to the IPO. Therefore, this the buyout is an area in which private ordering should yield to the mandate of securities regulators who, in their role as protectors of investors and the public interest writ large, should be concerned with both process and substance in the buyout of a DCS founder. ${ }^{147}$

Securities regulators have focused to some extent on process as being central to the interests of subordinate shareholders in the DCS. Canadian law requires independent valuations and majority of minority security holder approvals for specified types of transactions, such as issuer bids, insider bids, business combinations and related party transactions. For example, the offeror of an insider bid (that may occur if a founder is being bought out) must provide minority shareholders with a formal, independent valuation of the proposed transaction at the offeror's expense. ${ }^{148}$ But the law regarding valuations has been somewhat controversial especially in terms of information that is disclosed to shareholders. ${ }^{149}$ Current law should specifically mandate that the board form a special committee of independent directors and that it make a recommendation to the subordinate shareholders. It should require independent valuations and majority of the minority approval of buyouts of the founder in a DCS firm.

While US securities law contains little regulation relating to $\mathrm{DCS},{ }^{150}$ regulators in some jurisdictions seem to be moving towards greater regulation. In Canada, the OSC recently

\footnotetext{
147 See Ontario Securities Commission, supra note 11. See also Ontario Securities Commission Rule 56-601 "Restricted Shares" which compels issues of DCS to make specific disclosure regarding characteristics of shares in offering documents.

148 Ibid s.2.3.

${ }^{149}$ See Re InterOil Corporation, 2017 YKSC 16.

150 Robert J. Jackson Jr., "Perpetual Dual-Class Stock: The Case Against Corporate Royalty”, (Address delivered at the UC Berkeley School of Law, 15 February 2018), online: < https://www.sec.gov/news/speech/perpetual-dualclass-stock-case-against-corporate-royalty\#_ftn19>.
} 
published guidance regarding minority shareholders in conflict of interest transactions. ${ }^{151}$ They isolate several key areas for their review of material conflict transactions, namely: timely formation of special committees, a broad committee mandate, independence of the committee members, reluctance of over-relying on fairness opinions, and considerations of what is in the best interests of both the corporation and its minority shareholders. ${ }^{152}$ As this article has suggested, these are much-needed protections; one should therefore question why the regulatory approach is in the form of "guidance" as opposed to mandatory law.

\section{Conclusion}

This article fills a conspicuous gap in the scholarly literature first, by comprehensively addressing a vast body of literature relating to DCS; and second, by providing empirical data regarding the governance of DCS firms beyond the presence of sunrise and sunset provisions. The summary data suggest that the governance of DCS firms is not uniform and DCS firms tend not to adopt governance measures voluntarily. In particular, a large proportion of DCS firms have no majority of the minority voting provisions and no independent board chair. By contrast, almost half of the DCS firms have a sunset clause and a majority of independent directors the latter of which is contained in best practice guidelines for all public firms. Finally, just under one-third of DCS firms have change of control provisions over and above existing law. These data invite further analysis about the governance of DCS in the context of the associated regulatory regime, a regime that is mandated to protect investors' interests which obviously includes subordinate shareholders in the DCS context. Mandatory sunset provisions, disclosure relating to shareholder votes, and buyout protections would at least partially address governance weaknesses inherent in DCS firms.

\footnotetext{
151 Canadian Securities Administrators, Multilateral CSA Staff Notice 61-302 Staff Review and Commentary on Multilateral Instrument 61-101 Protection of Minority Security Holders in Special Transactions (27 July 2017), online: <https://www.osc.gov.on.ca/documents/en/Securities-Category6/csa_20170727_61-302_sn-staff-review.pdf> 152 Mindy B Gilbert, Patricia Olasker, et al, "Boards Beware: Regulators Actively Monitoring Related Party Transactions Authors" (2017) Davies LLP, online: <https://www.dwpv.com/en/Insights/Publications/2017/BoardsBeware-Regulators-Actively-Monitoring-Related-Party-Transactions $>$.
} 


\section{APPENDIX 1 \\ Scholarly Research on Dual Class Shares Structures}

This Appendix sets forth five tables as follows: empirical studies that find that DCS are detrimental to investors or firm value; studies that find that DCS have a positive effect on firm value; non empirical studies relating to DCS; governance and other articles; and government sources cited in this paper.

Table of Studies Finding DCS are Harmful to Investors/Firm Value

\begin{tabular}{|c|c|c|c|}
\hline Author(s) & Sample & Data Source & Main Findings \\
\hline $\begin{array}{l}\text { Li and Zaiats } \\
\text { (2017) }\end{array}$ & 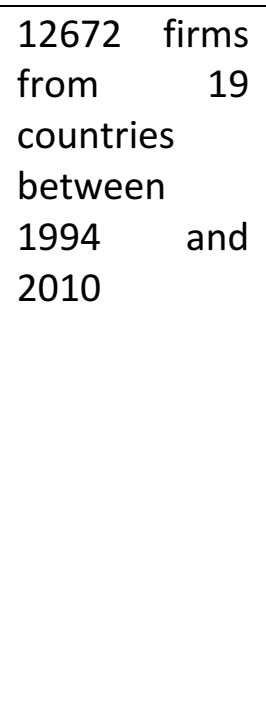 & $\begin{array}{l}\text { Datastream, } \\
\text { Worldscope, } \\
\text { International } \\
\text { I/B/E/S, TRTH } \\
\text { (managed by the } \\
\text { Securities } \\
\text { Industry } \\
\text { Research Center } \\
\text { of Asia-Pacific } \\
\text { (SIRCA), Djankov } \\
\text { et al. (2008), La } \\
\text { Porta et al. } \\
\text { (1998), Doidge } \\
\text { (2004), }\end{array}$ & $\begin{array}{l}\text { Dual class firms are associated with poorer } \\
\text { information environments and increase accrual-based } \\
\text { earning management, which is consistent with the } \\
\text { notion that managers of dual class firms exhibit } \\
\text { incentives to conceal private control benefits from } \\
\text { outside shareholders. They also find that DCS } \\
\text { structures weaken the mitigating impact of investor } \\
\text { protection on earnings management and that, } \\
\text { following unification, firms experience an } \\
\text { improvement in information environment and a } \\
\text { decrease in earning manipulation. }\end{array}$ \\
\hline $\begin{array}{l}\text { Hossain } \\
(2014)\end{array}$ & $\begin{array}{l}\text { Corporate } \\
\text { takeovers } \\
\text { between } \\
1996 \text { and } \\
2009(12,404 \\
\text { transactions } \\
\text { in total) }\end{array}$ & Compustat, CRSP & $\begin{array}{l}\text { Hossain finds that single class firms experience higher } \\
\text { abnormal returns around acquisition announcements } \\
\text { and that dual class firms primarily undertake value } \\
\text { destroying acquisitions. Long-term post-acquisition } \\
\text { operating performances for single class firms are also } \\
\text { found to be significantly higher. Overall, the results } \\
\text { indicate that there is an agency issue inherent within } \\
\text { a dual-class share structure. }\end{array}$ \\
\hline
\end{tabular}




\begin{tabular}{|c|c|c|c|}
\hline $\begin{array}{l}\text { Amoako-Adu, } \\
\text { Smith, } \\
\text { Baulkaran } \\
\text { (2011) }\end{array}$ & $\begin{array}{l}32 \\
\text { unifications } \\
\text { of DCS on TSX } \\
\text { from 1989- } \\
2010 .\end{array}$ & TSX & $\begin{array}{l}\text { Authors find that firms that eliminate DCS structures } \\
\text { experience increased stock performance via the } \\
\text { opportunity to restructure the board. }\end{array}$ \\
\hline $\begin{array}{l}\text { Arugaslan, } \\
\text { Cook, and } \\
\text { Kieschnic } \\
(2010)\end{array}$ & $\begin{array}{l}6600 \text { IPOs } \\
\text { between } \\
\text { January } 1 \text {, } \\
1980 \text { and } \\
\text { December } \\
31,2008 \text {. }\end{array}$ & $\begin{array}{l}\text { Thomson's New } \\
\text { Issues }\end{array}$ & $\begin{array}{l}\text { Authors find that managers do not prefer DCS to } \\
\text { necessarily invest in long-term projects; rather, it is } \\
\text { done mainly to retain control of the company. Insiders } \\
\text { do this to diversify their own portfolios and maintain } \\
\text { control. }\end{array}$ \\
\hline $\begin{array}{l}\text { Masulis, } \\
\text { Wang \& Xie } \\
(2009)\end{array}$ & $\begin{array}{l}\text { U.S } \\
\text { Class } \text { Dual- } \\
\text { from } 1994 \text { to } \\
2002 .\end{array}$ & $\begin{array}{l}\text { GIM, Compustat, } \\
\text { and CRSP }\end{array}$ & $\begin{array}{l}\text { As divergence widens between insider voting and cash } \\
\text { flow rights, corporate cash holdings are worth less to } \\
\text { outside shareholders, CEOs receive higher } \\
\text { compensation, managers make shareholder value- } \\
\text { destroying acquisitions more often, and capital } \\
\text { expenditures contribute less to shareholder value. }\end{array}$ \\
\hline $\begin{array}{lr}\text { King } & \text { and } \\
\text { Santor } & (2008)\end{array}$ & $\begin{array}{l}613 \text { Canadian } \\
\text { firms from } \\
1998 \text { to } 2005\end{array}$ & $\begin{array}{l}\text { SEDAR, Statistics } \\
\text { Canada } \\
\text { InterCorporate } \\
\text { Ownership Data, } \\
\text { Financial Post } \\
\text { Top } 500\end{array}$ & $\begin{array}{l}\text { Authors find that family owned firms that use DCS } \\
\text { have valuations that are lower by } 17 \% \text { on average } \\
\text { relative to widely held firms, despite having similar } \\
\text { ROA and financial leverage }\end{array}$ \\
\hline $\begin{array}{l}\text { Smart, } \\
\text { Thirumalai, } \\
\text { and Zutter } \\
(2008)\end{array}$ & $\begin{array}{l}2622 \text { IPOs } \\
\text { (including } \\
253 \text { dual class } \\
\text { issues) }\end{array}$ & $\begin{array}{l}\text { Disclosure New } \\
\text { Issues } \\
\text { (Disclosure Inc.) }\end{array}$ & $\begin{array}{l}\text { Dual-class firms trade at lower prices than do single- } \\
\text { class firms, both at the IPO and for at least the } \\
\text { subsequent five years. They also find that general CEO } \\
\text { turnover is sensitive to firm performance for single but } \\
\text { not dual class firms. They further note that when dual } \\
\text { class firms unify their share classes, statistically and } \\
\text { economically significant value gains occur. }\end{array}$ \\
\hline
\end{tabular}




\begin{tabular}{|c|c|c|c|}
\hline $\begin{array}{l}\text { Dyck and } \\
\text { Zingales } \\
(2004)\end{array}$ & $\begin{array}{l}393 \text { control } \\
\text { transactions } \\
\text { between } \\
1990 \text { and } \\
2000 \text { in } 39 \\
\text { countries }\end{array}$ & $\begin{array}{l}\text { SDC } \\
\text { international } \\
\text { mergers and } \\
\text { acquisitions } \\
\text { database }\end{array}$ & $\begin{array}{l}\text { Authors find that higher benefits of control are } \\
\text { associated with more concentrated ownership. } \\
\text { However, public pressures can reduce private benefits } \\
\text { of control though this may not necessarily translate } \\
\text { into increased shareholder value. }\end{array}$ \\
\hline $\begin{array}{l}\text { Gompers, } \\
\text { Ishii, and } \\
\text { Metrick } \\
\text { (2004) }\end{array}$ & $\begin{array}{l}\text { Dual Class } \\
\text { firms listed in } \\
\text { the United } \\
\text { States }\end{array}$ & $\begin{array}{l}\text { Securities Data } \\
\text { Company (SDC), } \\
\text { Center for } \\
\text { Research in } \\
\text { Security Prices } \\
\text { (CRSP), and the } \\
\text { Investor } \\
\text { Responsibility } \\
\text { Research Center }\end{array}$ & $\begin{array}{l}\text { Authors find that the relationship of firm value to cash } \\
\text { flow rights is positive and concave and the relationship } \\
\text { to voting rights is negative and convex. Overall, the } \\
\text { evidence is consistent with an entrenchment effect of } \\
\text { voting control that leads managers to } \\
\text { underinvestment and an incentive effect of cash flow } \\
\text { ownership that induces managers to pursue } \\
\text { aggressive strategies. }\end{array}$ \\
\hline $\begin{array}{l}\text { Smart and } \\
\text { Zutter (2003) }\end{array}$ & $\begin{array}{l}2622 \text { IPOs } \\
(253 \text { dual } \\
\text { class issues) }\end{array}$ & $\begin{array}{l}\text { Disclosure New } \\
\text { Issues } \\
\text { (Disclosure Inc.) }\end{array}$ & $\begin{array}{l}\text { Authors find that DCS firms trade at lower prices } \\
\text { relative to earnings and sales than single-class IPOs. } \\
\text { This pricing difference, combined with a finding that } \\
\text { managers earn higher compensation, suggests that } \\
\text { dual-class ownership structures protect private } \\
\text { control benefits. }\end{array}$ \\
\hline $\begin{array}{l}\text { Amoako-Adu } \\
\text { and Smith } \\
(2001)\end{array}$ & $\begin{array}{l}32 \\
\text { unifications } \\
\text { of dual class } \\
\text { companies } \\
\text { from } 1989 \text { to } \\
2010\end{array}$ & & $\begin{array}{l}\text { Authors find that there is some value to DCS, but point } \\
\text { to many examples of DCS and tightly-controlled firms } \\
\text { suggest that DCS should be permitted but closely- } \\
\text { monitored to prevent agency problems. }\end{array}$ \\
\hline
\end{tabular}

Table of Studies Finding Benefits or no Impact of DCS Firms on Firm Performance or Investor Interests

\begin{tabular}{|l|l|l|l}
\hline Author(s) & Sample & Data Source & Main Findings \\
\hline Anderson, & $2379 \quad$ firms & Russell 3000, & Authors find that adopt a buy-and-hold strategy of \\
Ottolenghi, & $\begin{array}{l}\text { (or 24,724 } \\
\text { firm-year }\end{array}$ & $\begin{array}{l}\text { CompuStat, Center } \\
\text { on Research in }\end{array}$ & $\begin{array}{l}\text { DCS family firms earns excess returns of 350 basis } \\
\text { points per year relative to the benchmark of single }\end{array}$ \\
\hline
\end{tabular}




\begin{tabular}{|c|c|c|c|}
\hline $\begin{array}{l}\text { and } \quad \text { Reeb } \\
(2017)\end{array}$ & $\begin{array}{l}\text { observations) } \\
\text { spanning } \\
\text { from } 2001 \\
\text { through } 2015\end{array}$ & $\begin{array}{l}\text { Securities Prices } \\
\text { (CRSP) }\end{array}$ & $\begin{array}{l}\text { class nonfamily firms. They argue that "after } \\
\text { controlling for time, industry and a wide variety of } \\
\text { firm-specific factors, our analysis does not lend } \\
\text { support to the notion that DCS harm outside } \\
\text { investors. Rather, DCS shares have no effect on } \\
\text { outside investors. When family shareholders own the } \\
\text { superior shares, however, they find that the } \\
\text { subordinate shareholders earn a return premium on } \\
\text { their investment. They suggest that family control } \\
\text { players a key role in the effect of DCS on minority } \\
\text { shareholders. }\end{array}$ \\
\hline $\begin{array}{l}\text { Gabriel } \\
\text { Morey } \\
\text { (Council of } \\
\text { Institutional } \\
\text { Investors) } \\
(2017) \\
\end{array}$ & $\begin{array}{l}1762 \text { Russell } \\
3000 \text { firms }\end{array}$ & $\begin{array}{l}\text { FactSet and SEC } \\
\text { data }\end{array}$ & $\begin{array}{l}\text { Author finds that DCS neither increase nor decrease a } \\
\text { company's annualized return on invested capital } \\
\text { (ROIC). }\end{array}$ \\
\hline $\begin{array}{l}\text { Winden } \\
\text { (2017) }\end{array}$ & $\begin{array}{l}123 \text { U.S. } \\
\text { public firms }\end{array}$ & $\begin{array}{l}\text { Institutional } \\
\text { Shareholder } \\
\text { Services } \\
\text { (ISS), company } \\
\text { charters in the } \\
\text { Takeover Defense } \\
\text { database of } \\
\text { SharkRepellant.net } \\
\text { provided by FactSet }\end{array}$ & $\begin{array}{l}\text { Author finds that entrepreneurs and founders use } \\
\text { DCS to pursue long-term objectives and gain } \\
\text { immunity from short-term shareholder whims. } \\
\text { However, sunset clauses and other protections for } \\
\text { shareholders should be included to ensure } \\
\text { managerial accountability and offer shareholder a } \\
\text { voice in governance. }\end{array}$ \\
\hline $\begin{array}{l}\text { Jordan, } \begin{array}{l}\text { Kim, } \\
\text { and } \\
(2016)\end{array} \\
\end{array}$ & $\begin{array}{l}\text { Dual-class } \\
\text { and single- } \\
\text { class firms } \\
\text { from } 1994 \text { to } \\
2011\end{array}$ & $\begin{array}{l}\text { Compustat, } \\
\text { Gompers et al. } \\
\text { (2010) and Smart } \\
\text { and Zutter (2003) } \\
\text { and supplement } \\
\text { the sample by } \\
\text { hand-collecting } \\
\text { dual-class firms }\end{array}$ & $\begin{array}{l}\text { Authors find that DCS firms face lower short-term } \\
\text { market pressure than single-class firms. They also } \\
\text { find that DCS firms tend to have more growth } \\
\text { opportunities (higher sales growth and R\&D intensity) } \\
\text { and DCS increase the market valuation of high growth } \\
\text { firms. }\end{array}$ \\
\hline $\begin{array}{l}\text { Nuesch } \\
(2016)\end{array}$ & $\begin{array}{l}\text { Yearly } \\
\text { observations } \\
\text { from publicly } \\
\text { listed Swiss } \\
\text { firms from } \\
1990 \text { to } 1999\end{array}$ & $\begin{array}{l}\text { Swiss Stock Guide, } \\
\text { Thomas Reuters } \\
\text { Datastream. }\end{array}$ & $\begin{array}{l}\text { Author finds that DCS neither harm nor benefit firm } \\
\text { performance on average. DCS increase firm } \\
\text { performance if the firm requires external finance and } \\
\text { decrease firm performance if the firm does not } \\
\text { require external finance. }\end{array}$ \\
\hline
\end{tabular}




\begin{tabular}{|c|c|c|c|}
\hline 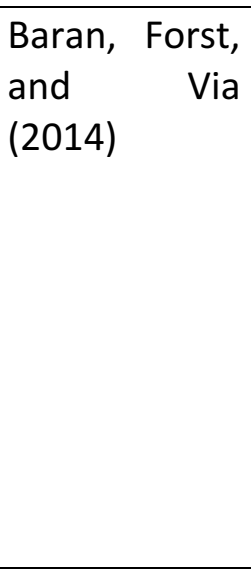 & $\begin{array}{l}\text { Dual-class } \\
\text { shares in the } \\
\text { USA from } \\
\text { between } \\
2000-2008 . \\
\text { Excludes } \\
\text { foreign and } \\
\text { financial } \\
\text { firms. }\end{array}$ & $\begin{array}{l}\text { Center for } \\
\text { Research } \\
\text { Security Prices at } \\
\text { the University of } \\
\text { Chicago (CRSP), } \\
\text { Compustat, } \\
\text { National Bureau of } \\
\text { Economic Research } \\
\text { (NBER) patent } \\
\text { database, and } \\
\text { EDGAR. }\end{array}$ & $\begin{array}{l}\text { Authors find that the enhanced managerial } \\
\text { entrenchment permitted in the DCS firm fosters } \\
\text { innovative management culture. Authors find that } \\
\text { there is a "positive relationship" between the } \\
\text { "wedge" (i.e. the differential between insider voting } \\
\text { rights and cash flow rights compared against non- } \\
\text { insider shareholders) and both patents and citations. } \\
\text { They contend that this "benefits shareholders as } \\
\text { excess managerial entrenchment increases." }\end{array}$ \\
\hline $\begin{array}{l}\text { Humphery- } \\
\text { Jenner (2014) }\end{array}$ & $\begin{array}{l}3935 \\
\text { acquisitions } \\
\text { that are } \\
\text { made } \\
\text { between } \\
1990 \text { and } \\
2005 \text { and } \\
\text { are by } \\
\text { companies } \\
\text { listed in the } \\
\text { US. }\end{array}$ & $\begin{array}{l}\text { SDC platinum and } \\
\text { Center for } \\
\text { Research } \quad \text { in } \\
\text { Security Prices at } \\
\text { the University of } \\
\text { Chicago (CRSP) }\end{array}$ & $\begin{array}{l}\text { Author finds that hard-to-value firms that are } \\
\text { entrenched make acquisitions that generate more } \\
\text { shareholder wealth and are more likely to increase } \\
\text { corporate innovation. This entrenchment is a } \\
\text { function of anti-takeover provisions which can be a } \\
\text { function of DCS structures. }\end{array}$ \\
\hline $\begin{array}{l}\text { Spizzirri and } \\
\text { Fullbrook } \\
\text { (2013) }\end{array}$ & $\begin{array}{l}435 \text { firms for } \\
\text { all or part of } \\
\text { the period } \\
\text { between } \\
2002 \text { and } \\
2012 \text {. }\end{array}$ & $\begin{array}{l}\text { S\&P/TSX } \\
\text { Composite Index } \\
\text { (TSX Index) }\end{array}$ & $\begin{array}{l}\text { Authors find that Canadian family-controlled firms } \\
\text { benefit minority shareholders significantly despite } \\
\text { contrary academic research. }\end{array}$ \\
\hline $\begin{array}{l}\text { Jog, Zhu, and } \\
\text { Dutta (2010) }\end{array}$ & $\begin{array}{l}\text { All Canadian } \\
\text { publicly listed } \\
\text { firms from } \\
1996 \text { to } 2005 \\
\text { (10,366 firm- } \\
\text { year } \\
\text { observations) }\end{array}$ & $\begin{array}{lr}\text { Stock } & \text { Guide } \\
\text { database, } & \text { TSX } \\
\text { Month Review } & \end{array}$ & $\begin{array}{l}\text { Authors do not find that restrictive voting share (RVS) } \\
\text { structures lower firm value, operating performance, } \\
\text { or stock performance relative to non-RVS firms in } \\
\text { Canada. Also, they do not find evidence of } \\
\text { shareholder value expropriation in key financial } \\
\text { decisions, such as mergers and acquisitions and } \\
\text { dividend payments. }\end{array}$ \\
\hline Valsan (2007) & $\begin{array}{l}1,452 \text { firms in } \\
\text { the spring of } \\
2007\end{array}$ & $\begin{array}{l}\text { Toronto } \\
\text { Exchange }\end{array}$ & $\begin{array}{l}\text { Author finds that Canada's large geographic expanse } \\
\text { and its demographic blocs create conditions which } \\
\text { favour tightly-controlled family firms. This trend is } \\
\text { shifting away towards wider shareholding to the } \\
\text { benefit of minority shareholders while reducing } \\
\text { agency costs. }\end{array}$ \\
\hline
\end{tabular}




\begin{tabular}{|c|c|c|c|}
\hline $\begin{array}{l}\text { Ben-Amar } \\
\text { and André } \\
(2006)\end{array}$ & $\begin{array}{l}327 \text { Canadian } \\
\text { Transactions } \\
\text { from 1998- } \\
2002\end{array}$ & $\begin{array}{l}\text { Thomson Financial } \\
\text { Securities Data's } \\
\text { SDC Platinum } \\
\text { Worldwide } \\
\text { Mergers } \\
\text { Acquisitions } \\
\text { Database }\end{array}$ & $\begin{array}{l}\text { Authors do not find that separation of ownership and } \\
\text { control leads to value destroying M\&A. }\end{array}$ \\
\hline $\begin{array}{l}\text { Dimitrov and } \\
\text { Jain (2006) }\end{array}$ & $\begin{array}{l}178 \text { firms } \\
\text { that changed } \\
\text { from a one- } \\
\text { share one- } \\
\text { vote firm into } \\
\text { a dual class } \\
\text { company } \\
\text { between } \\
1979 \text { and } \\
1998\end{array}$ & $\begin{array}{l}\text { Center for } \\
\text { Research in } \\
\text { Security Prices at } \\
\text { the University of } \\
\text { Chicago (CRSP), } \\
\text { Dow Jones News } \\
\text { Wire, Securities } \\
\text { and Exchange } \\
\text { Commission }\end{array}$ & $\begin{array}{l}\text { Authors find DCS recapitalizations to be shareholder } \\
\text { value-enhancing initiatives. In particular, dual class } \\
\text { recapitalizing firms grew faster than firms in a control } \\
\text { group and the growth was beneficial to shareholders; } \\
\text { the stockholders, on average, earned significant } \\
\text { positive abnormal returns of } 23.11 \% \text { in a period of } 4 \\
\text { years following the announcement. Abnormal } \\
\text { returns of } 52.61 \% \text { were observed for dual-class firms } \\
\text { that issued equity. }\end{array}$ \\
\hline $\begin{array}{l}\text { Cronqvist } \\
\text { and Nilsson } \\
(2003)\end{array}$ & $\begin{array}{l}309 \text { Swedish } \\
\text { Firms from } \\
1991-1997 .\end{array}$ & $\begin{array}{l}\text { Swedish Securities } \\
\text { Register Centre }\end{array}$ & $\begin{array}{l}\text { Authors find that examples of Swedish CMS / DCS } \\
\text { structures have a lower return on assets and } \\
\text { command a lower share price (owing to the agency } \\
\text { costs associated with such structures). However, such } \\
\text { structures may be beneficial to society by allowing } \\
\text { founders to seek out longer-term investment returns. }\end{array}$ \\
\hline $\begin{array}{l}\text { Daines and } \\
\text { Klausner } \\
(2001)\end{array}$ & $\begin{array}{l}10 \text { US Firms } \\
\text { (106 firms } \\
\text { with venture } \\
\text { capital } \\
\text { investment, } 91 \\
\text { with LBO } \\
\text { specialist } \\
\text { investment, } \\
\text { and } 113 \\
\text { others) that } \\
\text { went public } \\
\text { between } \\
\text { January } 1 \\
1994 \text { - July } 1 \\
1997\end{array}$ & $\begin{array}{l}\text { Securities Data } \\
\text { Corporation, Pratt's } \\
\text { Guide to Venture } \\
\text { Capital Sources, } \\
\text { LEXIS/NEXIS M\&A }\end{array}$ & $\begin{array}{l}\text { Authors argue that there is no strong evidence to suggest } \\
\text { that anti-takeover provisions (including DCS) post-IPO } \\
\text { supports the private benefit hypothesis. There may be } \\
\text { idiosyncratic benefits which managers seek to preserve. } \\
\text { Ultimately, anti-takeover provision needs to be studied } \\
\text { further to yield more satisfactory explanations as to their } \\
\text { role in firms during IPOs. }\end{array}$ \\
\hline $\begin{array}{l}\text { Bergstrom } \\
\text { and Rydqvist } \\
(1990)\end{array}$ & 45 US firms & $\begin{array}{l}\text { Swedish Stock } \\
\text { Exchange }\end{array}$ & $\begin{array}{l}\text { Authors study Swedish DCS firms and find that there } \\
\text { is no evidence of wealth expropriation by controlling } \\
\text { shareholders; but cannot definitively say that this } \\
\text { expropriation does not happen. }\end{array}$ \\
\hline
\end{tabular}




\begin{tabular}{|l|l|l|l}
\hline Partch (1987) & $\begin{array}{l}\text { 44 firms that } \\
\text { created MVS } \\
\text { from 1963- } \\
1985\end{array}$ & $\begin{array}{l}\text { S\&P Security } \\
\text { Owner's Stock } \\
\text { Guide and Moody's } \\
\text { Manuals }\end{array}$ & $\begin{array}{l}\text { Author finds that firms that create DCS structures do } \\
\text { not affect shareholder wealth. }\end{array}$ \\
\hline $\begin{array}{l}\text { DeAngelo } \\
\text { and } \\
\text { DeAngelo } \\
\text { (1985) }\end{array}$ & 45 US firms & $\begin{array}{l}\text { Standard and } \\
\text { Poor's Security } \\
\text { Owners' Stock } \\
\text { Guide, The Bond } \\
\text { Quotation Record, } \\
\text { ISL Daily Stock } \\
\text { Price Guide }\end{array}$ & $\begin{array}{l}\text { Authors find that DCS firms can be viewed as an } \\
\text { intermediate organization between widely dispersed } \\
\text { publicly owned corporation and a closely-held firm. } \\
\text { Authors find that DCS structures value managerial } \\
\text { vote control though authors do not specifically } \\
\text { elaborate on the beneficial or negative consequences } \\
\text { of such structures. }\end{array}$ \\
\hline
\end{tabular}

Table of Theoretical Studies of DCS Firms on Firm Performance or Investor Interests

\begin{tabular}{|c|c|c|c|}
\hline Author(s) & Sample & Data Source & Main Findings \\
\hline $\begin{array}{l}\text { Bebchuk and } \\
\text { Kastiel (2017) }\end{array}$ & $\begin{array}{l}\text { Various other } \\
\text { surveys of } \\
\text { DCS in } \\
\text { academic } \\
\text { papers and } \\
\text { case studies } \\
\text { featuring } \\
\text { SNAP. }\end{array}$ & & $\begin{array}{l}\text { Authors argue that DCS have detrimental effects } \\
\text { which may distort and misalign managerial interests } \\
\text { against those with public investors. These problems } \\
\text { are more pronounced as longer time passes from the } \\
\text { IPO. Authors propose remedy of finite DCS duration } \\
\text { via sunset clauses to reduce risks of perpetual DCS } \\
\text { structures. }\end{array}$ \\
\hline $\begin{array}{l}\text { Goshen and } \\
\text { Squire (2017) }\end{array}$ & $\begin{array}{l}\text { Select } \\
\text { company } \\
\text { cases like } \\
\text { Facebook } \\
\text { and Google }\end{array}$ & & $\begin{array}{l}\text { Authors argue that firms are best suited to consider } \\
\text { the context in designing an optimal governance } \\
\text { structure. This is more beneficial than having } \\
\text { mandatory structures for certain firms under what the } \\
\text { authors call the "Principal Cost Theory". }\end{array}$ \\
\hline $\operatorname{Lin}(2017)$ & $\begin{array}{ll}\text { Literature } & \\
\text { review of } \\
\text { past } & \\
\text { empirical } \\
\text { studies on } \\
\text { DCS. }\end{array}$ & & $\begin{array}{l}\text { Author argues that DCS structures should not be } \\
\text { banned entirely; but, they should be rolled back to re- } \\
\text { empower shareholders with the "one share, one vote" } \\
\text { principle. }\end{array}$ \\
\hline
\end{tabular}




\begin{tabular}{|c|c|c|c|}
\hline $\begin{array}{l}\text { Nicholas and } \\
\text { Marsh (2017) }\end{array}$ & $\begin{array}{l}\text { Case studies } \\
\text { from } \\
\text { examples like } \\
\text { SNAP and } \\
\text { Hollinger }\end{array}$ & & $\begin{array}{l}\text { Authors argue that DCS structures create possibilities } \\
\text { of managerial misconduct. While institutional } \\
\text { investors may be amenable to longer-term gains } \\
\text { flowing from long-term managerial protection desires } \\
\text { by DCS structures, authors recommend such investors } \\
\text { still remain vigilant to the dangers of management } \\
\text { misconduct. }\end{array}$ \\
\hline $\begin{array}{l}\text { Sharfman } \\
(2017)\end{array}$ & $\begin{array}{l}\text { Case study on } \\
\text { SNAP IPO }\end{array}$ & $\begin{array}{l}\text { Various news } \\
\text { sources }\end{array}$ & $\begin{array}{l}\text { Author argues that DCS structures are socially } \\
\text { beneficial. They enable firms to remain innovative and } \\
\text { competitive and against the whims of less competent } \\
\text { shareholders. Mandatory provisions against DCS (e.g. } \\
\text { overly restrictive sunset provisions) are detrimental to } \\
\text { creation of value-maximizing companies like Snap, } \\
\text { Alphabet, Berkshire Hathaway, etc. }\end{array}$ \\
\hline $\begin{array}{l}\text { Sharfman } \\
(2017)\end{array}$ & & & $\begin{array}{l}\text { Author argues that DCS offer great value for firms } \\
\text { entering into IPOs. This method of private ordering } \\
\text { should be supported with its costs (and benefits) of } \\
\text { this structure already factored into the market price of } \\
\text { the offered shares. }\end{array}$ \\
\hline Anand (2016) & & & $\begin{array}{l}\text { Author argues that DCS and MVS structures } \\
\text { undermine minority shareholders' rights while giving } \\
\text { holders of DCS and MVS holders incentive to self- } \\
\text { enrich. DCS/MVS structures should be reformed to } \\
\text { rebalance the currently disproportionate risks that } \\
\text { minority shareholders carry in relation to those with } \\
\text { greater voting rights. }\end{array}$ \\
\hline $\begin{array}{l}\text { Goshen and } \\
\text { Hamdan } \\
(2016)\end{array}$ & $\begin{array}{l}\text { Various } \\
\text { academic } \\
\text { journal } \\
\text { articles and } \\
\text { case law. }\end{array}$ & & $\begin{array}{l}\text { Authors challenge idea that DCS and other methods of } \\
\text { maintaining managerial control as wrong-headed. } \\
\text { Rather, the authors contend that greater managerial } \\
\text { control comes from entrepreneurial/founders' desire } \\
\text { to pursue their business vision. }\end{array}$ \\
\hline $\begin{array}{l}\text { McCahery and } \\
\text { Veremeulen } \\
\text { (2016) }\end{array}$ & & & $\begin{array}{l}\text { Authors find that small/medium enterprises adopt various } \\
\text { anti-takeover provisions including DCS structures during } \\
\text { the lead-up to an IPO for fear of losing managerial control } \\
\text { over their company and losing their culture of innovation } \\
\text { and entrepreneurship. }\end{array}$ \\
\hline
\end{tabular}




\begin{tabular}{|c|c|c|c|}
\hline Shen (2016) & & & $\begin{array}{l}\text { Author argues that DCS structures should not be } \\
\text { prohibited, but there is a risk that shareholder } \\
\text { approval (or disapproval) of such DCS structures gives } \\
\text { rise to collective action problems which may reduce } \\
\text { shareholder oversight efficacy. }\end{array}$ \\
\hline $\begin{array}{ll}\text { Wang, } & \text { Xie, } \\
\text { and } & \text { Zhu } \\
(2015) & \end{array}$ & & & $\begin{array}{l}\text { Authors find that from a governance perspective, } \\
\text { independent board members provide greater } \\
\text { monitoring over management. Prior industry } \\
\text { experience enhances this independent board member } \\
\text { oversight capacity. }\end{array}$ \\
\hline Wen (2014) & $\begin{array}{l}\text { Case study } \\
\text { focusing on } \\
\text { Google, } \\
\text { Facebook, } \\
\text { Readers } \\
\text { Digest, News } \\
\text { Corp }\end{array}$ & $\begin{array}{l}\text { Various news } \\
\text { sources (WSJ, NY } \\
\text { Times, WSJ, } \\
\text { Bloomberg), } \\
\text { company IPO } \\
\text { registration } \\
\text { statements with } \\
\text { the SEC. }\end{array}$ & $\begin{array}{l}\text { Author argues that DCS are "on balance" negative for } \\
\text { shareholders. Citing case studies of Google, Facebook, } \\
\text { Readers Digest, News Corp, Magna, and other } \\
\text { examples, author contends that DCS will limit benefits } \\
\text { to the private controlling shareholders while } \\
\text { neglecting broader shareholder benefits. }\end{array}$ \\
\hline Wong (2013) & & & $\begin{array}{l}\text { Author argues that all shareholders should be given } \\
\text { some voice in the Anglo-American "one share, one } \\
\text { vote" spirit of corporate structuring and to prevent } \\
\text { managerial self-entrenchment. }\end{array}$ \\
\hline $\begin{array}{l}\text { Chemmanur } \\
\text { and Jiao } \\
(2012)\end{array}$ & $\begin{array}{l}\text { Authors } \\
\text { models }\end{array}$ & & $\begin{array}{l}\text { Authors find that while there may be optimal } \\
\text { scenarios for both DCS and single-share structures, } \\
\text { DCS structures create risks where entrenched } \\
\text { managers will not deliver as strong a return as argued } \\
\text { by DCS proponents. }\end{array}$ \\
\hline $\begin{array}{l}\text { Loureiro } \\
(2012)\end{array}$ & $\begin{array}{l}\text { Author's own } \\
\text { model }\end{array}$ & & $\begin{array}{l}\text { Author argues that shareholder proxy access } \\
\text { enhances opportunities to elect independent board } \\
\text { members. In turn, this enhances greater governance } \\
\text { over corporate management. }\end{array}$ \\
\hline
\end{tabular}




\begin{tabular}{|c|c|c|}
\hline $\begin{array}{l}\text { Ferreira and } \\
\text { Adams } \\
(2008)\end{array}$ & $\begin{array}{l}\text { Various } \\
\text { academic } \\
\text { studies on } \\
\text { DCS }\end{array}$ & $\begin{array}{l}\text { Authors conduct an empirical literature review of DCS } \\
\text { studies and find a fairly equal number of empirical } \\
\text { papers which favour and disregard DCS structures. } \\
\text { Generally, DCS structures are prominent in the US and } \\
\text { somewhat in the UK, but is decreasing in popularity in } \\
\text { Europe. }\end{array}$ \\
\hline $\begin{array}{l}\text { Hu and Black } \\
\text { (2008) }\end{array}$ & $\begin{array}{l}\text { Various } \\
\text { company } \\
\text { case studies } \\
\text { and US case } \\
\text { law. }\end{array}$ & $\begin{array}{l}\text { Authors argue that phenomenon of worldwide equity } \\
\text { decoupling of economic and voting rights has led to a } \\
\text { need to regulate such equity structure altering } \\
\text { decisions. The disconnect between the benefits of } \\
\text { decoupling (from a financial and managerial control } \\
\text { stance) versus the corporate and legal governance } \\
\text { paradigm (which presumes coupled voting and } \\
\text { economic rights for shareholders) require regulatory } \\
\text { responses to the risks of decoupling. Examples of such } \\
\text { risks of non-regulation include the then unknown } \\
\text { consequences of decoupling in the Great Financial } \\
\text { Crisis. }\end{array}$ \\
\hline $\begin{array}{l}\text { Adams and } \\
\text { Ferreira } \\
(2007)\end{array}$ & $\begin{array}{l}\text { Authors own } \\
\text { models }\end{array}$ & $\begin{array}{l}\text { Authors' model shows that there are situations where } \\
\text { policies that enhance board independence may be } \\
\text { detrimental for shareholders in a sole board system, } \\
\text { but not for shareholders in a dual board system. }\end{array}$ \\
\hline $\begin{array}{l}\text { Khalil and } \\
\text { Magnan } \\
\text { (2007) }\end{array}$ & & $\begin{array}{l}\text { Authors argue that DCS offer comparable long-term } \\
\text { returns to investors compared against single-class } \\
\text { shares. Similarly, governance may only be one aspect } \\
\text { of an investor's decision-making criteria. }\end{array}$ \\
\hline $\begin{array}{l}\text { Ben-Ishai and } \\
\text { Puri (2006) }\end{array}$ & & $\begin{array}{l}\text { Authors argue that historical Canadian factors such as } \\
\text { nationalist corporate policy enabled Canadian firms to } \\
\text { have a higher DCS presence. This phenomenon } \\
\text { remains active today. Non-DCS shareholders have } \\
\text { pushed back against DCS and the problems of } \\
\text { permanent self-entrenchment and managerial control } \\
\text { by reducing investments. }\end{array}$ \\
\hline
\end{tabular}




\begin{tabular}{|c|c|c|}
\hline $\begin{array}{l}\text { Vecchialla, } \\
\text { Prudom and } \\
\text { Hamilton III } \\
\text { (1998) }\end{array}$ & & $\begin{array}{l}\text { Authors argue that self-entrenching managers are } \\
\text { "corporate vampires" that erode shareholder value. } \\
\text { DCS structures and other managerial protection } \\
\text { avenues should be regarded by shareholders with } \\
\text { suspicion. }\end{array}$ \\
\hline $\begin{array}{l}\text { Arrunada and } \\
\text { Paz-Ares } \\
(1995)\end{array}$ & & $\begin{array}{l}\text { Authors argue that the process of conversion to } \\
\text { DCS/MVS structures has been problematic for } \\
\text { shareholders. These situations create Prisoner's } \\
\text { Dilemma for shareholders who may be better off } \\
\text { cooperating and rejecting conversion even if the } \\
\text { conditions of the conversion will incentive individual } \\
\text { acceptance of the offer to convert. }\end{array}$ \\
\hline $\begin{array}{l}\text { Harris and } \\
\text { Raviv (1988) }\end{array}$ & $\begin{array}{l}\text { Authors' own } \\
\text { generated } \\
\text { models }\end{array}$ & $\begin{array}{l}\text { Authors set forth conditions where one-share/one- } \\
\text { vote models are socially optimal. Symmetrical } \\
\text { treatment of incumbents and rivals helps create } \\
\text { better management. This system is a check against } \\
\text { bad management seeking solely to self-entrench }\end{array}$ \\
\hline
\end{tabular}

Table of Studies Dealing with Agency Theory and Governance

\begin{tabular}{|c|c|c|c|}
\hline Author(s) & Sample & Data Source & Main Findings \\
\hline $\begin{array}{l}\text { Sauerwald, } \\
\text { Van } \\
\text { Oosterhout, } \\
\text { and Van } \\
\text { Essen (2016) }\end{array}$ & $\begin{array}{l}12,513 \\
\text { proposals } \\
\text { voted on in } \\
717 \text { firms } \\
\text { listed in } 15 \\
\text { Western } \\
\text { European } \\
\text { countries }\end{array}$ & ISS Global Meetings & $\begin{array}{l}\text { Authors find that shareholders voicing dissent are } \\
\text { indicative of concern for corporate governance. } \\
\text { Voting is therefore an expressive act. }\end{array}$ \\
\hline $\begin{array}{l}\text { lliev, Lins, } \\
\text { Miller, and } \\
\text { Roth (2015) }\end{array}$ & $\begin{array}{lr}8,160 & \text { firms } \\
\text { across } & 43 \\
\text { countries } & \end{array}$ & Form N-PX reports & $\begin{array}{l}\text { Authors find that the shareholder voting process is an } \\
\text { important mechanism by which corporate } \\
\text { governance is exercised around the world. Similarly, } \\
\text { institutional reforms which enhance voting should be } \\
\text { welcomed and likely offers value. Laws which } \\
\text { encourage such reforms and protect voting should be } \\
\text { welcomed. }\end{array}$ \\
\hline
\end{tabular}




\begin{tabular}{|c|c|c|c|}
\hline $\begin{array}{l}\text { Anand, } \\
\text { Milne, and } \\
\text { Purda (2012) }\end{array}$ & & & $\begin{array}{l}\text { Authors find that voluntary corporate governance } \\
\text { practices have increased in Canada and US standards. } \\
\text { Authors also find that when firms are given freedom } \\
\text { of choice under a best practice regime, they may } \\
\text { choose (sometimes more stringent) governance } \\
\text { practices contained in the legal regime of another } \\
\text { country. }\end{array}$ \\
\hline Anand (2011) & $\begin{array}{l}\text { Case Study on } \\
\text { Magna }\end{array}$ & Case Law & $\begin{array}{l}\text { Author finds that the OSC's failure to contemplate the } \\
\text { injuries to minority shareholders in the Magna } \\
\text { transactions means that the OSC did not fully } \\
\text { consider the public interest. The author argues that } \\
\text { the public interest consideration is vital to the role of } \\
\text { a securities regulator. }\end{array}$ \\
\hline $\begin{array}{l}\text { lacobucci } \\
\text { (2011) }\end{array}$ & $\begin{array}{l}\text { Case Study on } \\
\text { Magna }\end{array}$ & Case Law & $\begin{array}{l}\text { Author finds that while many governance issues } \\
\text { existed in terms of Magna's special committee not } \\
\text { identifying plausible benefits and beneficiaries of the } \\
\text { DCS structure change at Magna, the court had } \\
\text { considered broad evidence to approve the } \\
\text { arrangement. }\end{array}$ \\
\hline $\begin{array}{l}\text { Anand, } \\
\text { Milne, and } \\
\text { Purda (2010) }\end{array}$ & $\begin{array}{ll}1200 & \text { Firms } \\
\text { from } & 1993- \\
2003 & \end{array}$ & $\begin{array}{l}\text { TSX and TSX/S\&P } \\
\text { indices listing for } \\
\text { firms }\end{array}$ & $\begin{array}{l}\text { Authors find that voluntary board adoption of } \\
\text { governance mechanisms increase in both boards } \\
\text { comprising more independent directors and boards } \\
\text { comprising more non-independent directors. } \\
\text { However, independent boards place special } \\
\text { importance on maintaining board committees staffed } \\
\text { exclusively with independent directors and that their } \\
\text { ability to voluntarily adopt other monitoring } \\
\text { mechanisms is sensitive to the presence of a } \\
\text { controlling shareholder. }\end{array}$ \\
\hline $\begin{array}{l}\text { Jackling and } \\
\text { Johl (2009) }\end{array}$ & & & $\begin{array}{l}\text { The authors' findings suggest that a larger board size } \\
\text { has a positive impact on performance. Similarly, a } \\
\text { board's greater exposure to the external } \\
\text { environment improves access to various resources } \\
\text { and thus positively impacts performance. }\end{array}$ \\
\hline $\begin{array}{l}\text { Dahya, } \\
\text { Dimitrov and } \\
\text { McConnell } \\
\text { (2008) }\end{array}$ & $\begin{array}{lr}799 \quad \text { firms } \\
\text { from } & 22 \\
\text { countries } & \end{array}$ & $\begin{array}{l}\text { Credit Lyonnais } \\
\text { Securities Asia } \\
\text { (CLSA) corporate } \\
\text { governance scores }\end{array}$ & $\begin{array}{l}\text { Authors find that there is a positive relation between } \\
\text { board independence and corporate value. This } \\
\text { suggests that independent governance adds value to } \\
\text { shareholders. }\end{array}$ \\
\hline
\end{tabular}




\begin{tabular}{|c|c|c|c|}
\hline & & $\begin{array}{l}\text { and the Standard \& } \\
\text { Poor's } \quad(S \& P) \\
\text { transparency } \\
\text { rankings }\end{array}$ & \\
\hline $\begin{array}{l}\text { Anderson, } \\
\text { Melanson, } \\
\text { and Maly } \\
(2007)\end{array}$ & $\begin{array}{l}\text { Survey of } 658 \\
\text { directors } \\
\text { from Canada, } \\
\text { Australia, } \\
\text { New Zealand, } \\
\text { and the USA }\end{array}$ & & $\begin{array}{l}\text { Authors find that directors are seeking to balance } \\
\text { roles as corporate monitor of management and } \\
\text { collaborators with management. This is positive for } \\
\text { governance generally. }\end{array}$ \\
\hline $\begin{array}{l}\text { Chhaochharia } \\
\text { and Grinstein } \\
\text { (2007) }\end{array}$ & $\begin{array}{lr}\text { S\&P } & 500, \\
\text { Midcap } & 400, \\
\text { SmallCap } & 600\end{array}$ & $\begin{array}{l}\text { Investor } \\
\text { Responsibility } \\
\text { Research Centre } \\
\text { (IRRC) }\end{array}$ & $\begin{array}{l}\text { Authors find that general trends in directorships } \\
\text { moves towards greater independence during sample } \\
\text { period. Such a trend is found in all sizes of corporate } \\
\text { capitalizations. }\end{array}$ \\
\hline $\begin{array}{l}\text { Finegold, } \\
\text { Benson, and } \\
\text { Hecht (2007) }\end{array}$ & $\begin{array}{l}105 \text { studies } \\
\text { featuring } \\
\text { 1) statistical } \\
\text { tests of the } \\
\text { relationship } \\
\text { between } \\
\text { corporate } \\
\text { boards of } \\
\text { company } \\
\text { performance; } \\
\text { 2), were } \\
\text { published in } \\
\text { the main } \\
\text { peer- } \\
\text { reviewed } \\
\text { journals that } \\
\text { deal with } \\
\text { corporate } \\
\text { governance, } \\
\text { and } \\
\text { 3) appeared } \\
\text { after } 1989\end{array}$ & & $\begin{array}{l}\text { Authors summarize various academic studies dealing } \\
\text { with corporate performance post-SOX and NASDAQ / } \\
\text { NYSE reforms. Generally, the broad array of papers } \\
\text { show different perspectives of corporate governance. }\end{array}$ \\
\hline $\begin{array}{l}\text { Lee and } \\
\text { Carlson } \\
\text { (2007) }\end{array}$ & & & $\begin{array}{l}\text { The authors have found that post-SOX board } \\
\text { membership has increased in independence and in } \\
\text { board level. This has increased efficiency in } \\
\text { management oversight. }\end{array}$ \\
\hline
\end{tabular}




\begin{tabular}{|c|c|c|c|}
\hline Anand (2006) & & & $\begin{array}{l}\text { Firms should voluntarily adopt corporate governance } \\
\text { practices since they offer net benefits on a cost- } \\
\text { benefit analysis. Author finds that the enabling } \\
\text { regime offers better benefits in terms of governance. }\end{array}$ \\
\hline $\begin{array}{lr}\text { Black, Jang, } \\
\text { and } & \text { Kim } \\
(2005) & \end{array}$ & $\begin{array}{l}515 \text { Korean } \\
\text { companies }\end{array}$ & $\begin{array}{l}2001 \text { Korea Stock } \\
\text { Exchange survey }\end{array}$ & $\begin{array}{l}\text { Authors find that Korean firms with } 50 \% \text { outside } \\
\text { directors have } 0.13 \text { higher Tobin's q (roughly } 40 \% \\
\text { higher share price). Therefore, evidence supports } \\
\text { view that independent directors offer greater } \\
\text { benefits to shareholders. }\end{array}$ \\
\hline $\begin{array}{l}\text { Brennan and } \\
\text { McDermott } \\
(2004)\end{array}$ & & & $\begin{array}{l}\text { Authors find that Irish companies have increased the } \\
\text { trend towards board independence despite the } \\
\text { different criteria which may define "independence" }\end{array}$ \\
\hline $\begin{array}{l}\text { Tsipouri and } \\
\text { Xanthakis } \\
(2004)\end{array}$ & & & $\begin{array}{l}\text { Authors find that generally Greek firms comply with } \\
\text { OECD criteria for international best practices for good } \\
\text { corporate governance. }\end{array}$ \\
\hline Black (2001) & $\begin{array}{l}21 \text { Russian } \\
\text { Firms }\end{array}$ & $\begin{array}{l}\text { Brunswick Warburg } \\
\text { (Russian } \\
\text { investment bank). }\end{array}$ & $\begin{array}{l}\text { Author tentatively finds that Russian firms benefitted } \\
\text { from governance changes despite the weaker level of } \\
\text { legal and cultural emphasis on governance. }\end{array}$ \\
\hline $\begin{array}{l}\text { Bebchuk, } \\
\text { Kraakman } \\
\text { and Triantis } \\
\text { (1999) }\end{array}$ & $\begin{array}{l}\text { Authors' own } \\
\text { models }\end{array}$ & & $\begin{array}{l}\text { Authors discuss three basic forms of minority } \\
\text { shareholder control (stock pyramids, DCS, and cross- } \\
\text { ownership structures). Authors contend that any of } \\
\text { these forms (or hybrid combinations thereof) create } \\
\text { skewed incentives for controlling-minority } \\
\text { shareholders (CMS). This impacts the scope and } \\
\text { degree of control over that particular project choice. } \\
\text { Authors' model shows that agency costs increase } \\
\text { more rapidly as the fraction of equity cash-flow rights } \\
\text { for CMS decrease. Essentially, CMS structures more } \\
\text { likely arise as the possibility of private benefits for } \\
\text { CMS arises. }\end{array}$ \\
\hline $\begin{array}{l}\text { Shleifer and } \\
\text { Vishny (1986) }\end{array}$ & $\begin{array}{l}\text { Authors' own } \\
\text { models }\end{array}$ & & $\begin{array}{l}\text { The authors find that firms with a significant number } \\
\text { of small shareholders imply that the single small } \\
\text { shareholder has neither the power nor the incentive } \\
\text { to devote significant resources to monitor } \\
\text { management's behavior and undertake corrective } \\
\text { action when needed. }\end{array}$ \\
\hline
\end{tabular}




\begin{tabular}{|l|l|l}
\hline $\begin{array}{l}\text { Jensen and } \\
\text { Meckling } \\
(1976)\end{array}$ & $\begin{array}{l}\text { Authors classical paper that discusses the } \\
\text { characteristics related to agency costs. Authors find } \\
\text { that divergent interests between management and } \\
\text { shareholders can lead to agency costs, i.e. costs that } \\
\text { shareholders incur to ensure that directors and } \\
\text { managers do not place their own interests above the } \\
\text { corporation's. }\end{array}$ \\
\hline
\end{tabular}

Table of Government Sources

\begin{tabular}{|c|c|}
\hline Source & Summary \\
\hline 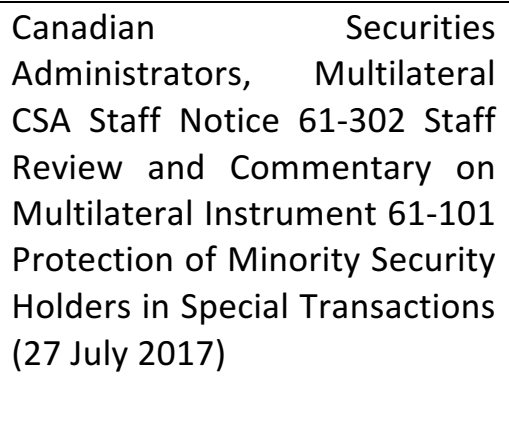 & $\begin{array}{l}\text { CSA commentary on MI 61-101. CSA reaffirms goal of MI } 61-101 \text { is that security } \\
\text { holders be treated in a manner that is fair and that is perceived to be fair. } \\
\text { MI } 61-101 \text { implements these principles through procedural protections for minority } \\
\text { security holders that include formal valuations, enhanced disclosure, and approval } \\
\text { by a majority of minority security holders. MI } 61-101 \text { also mandates the } \\
\text { involvement of a special committee of independent directors in specific } \\
\text { circumstances and } 61-101 \mathrm{CP} \text { recommends their use in all material conflict of } \\
\text { interest transactions. }\end{array}$ \\
\hline $\begin{array}{l}\text { Ontario Securities Commission, } \\
\text { Audit Committees, OSC NI 52- } \\
110(2011)\end{array}$ & $\begin{array}{l}\text { Regulators want to encourage reporting issuers to establish and maintain strong, } \\
\text { effective and independent audit committees. NI requires that audit committees also } \\
\text { be responsible for managing, on behalf of the shareholders, the relationship } \\
\text { between the issuer and the external auditors. }\end{array}$ \\
\hline $\begin{array}{l}\text { Ontario Securities Commission, } \\
\text { MI 61-101 Protection of } \\
\text { Minority Security Holders in } \\
\text { Special Transactions and } \\
\text { Companion Policy 61-101CP } \\
\text { Protection of Minority Security } \\
\text { Holders in Special Transactions } \\
\text { (1 February 2008) }\end{array}$ & $\begin{array}{l}\text { OSC and AMF expect that all security holders be treated in a manner that is fair and } \\
\text { that is perceived to be fair in matters of insider bids, issuer bids, business } \\
\text { combinations and related-party transactions. Document clarifies disclosure } \\
\text { requirements, director duties, and minority approval processes during these } \\
\text { transactions. }\end{array}$ \\
\hline $\begin{array}{l}\text { Ontario Securities Commission, } \\
\text { Disclosure of Corporate } \\
\text { Governance Practices, OSC NI } \\
58-101 \text { (2005) }\end{array}$ & $\begin{array}{l}\mathrm{NI} \text { requiring mandatory disclosure for independent directors and non-independent } \\
\text { directors, attendance record, residency, compensation, nomination, and other } \\
\text { criteria. }\end{array}$ \\
\hline $\begin{array}{l}\text { Ontario Securities Commission, } \\
\text { "Notice of Rule under the } \\
\text { Securities Act Rule } 56-501 \\
\text { Restricted Shares" (9 April } \\
\text { 1997) }\end{array}$ & $\begin{array}{l}\text { OSC notifies marketplace about the implementation of Rule 56-501 concerning } \\
\text { Restricted Shares. Substantively, the rule meant that an issuer shall not file a } \\
\text { prospectus, and prospectus exemptions are not available, in respect of a stock } \\
\text { distribution (as defined in the Rule), unless either the stock distribution or } \\
\text { reorganization (as defined) that resulted in the creation of the restricted shares } \\
\text { received minority approval. }\end{array}$ \\
\hline
\end{tabular}




\section{APPENDIX 2 \\ DCS Firms}

The dataset consists of the following DCS Firms listed on the TSX as of December 31, 2015

\begin{tabular}{|c|c|}
\hline Acasta Enterprises & Corby Spirit and Wine \\
\hline ADF Group & Corus Entertainment \\
\hline AGF Management & Cymbria Corp \\
\hline Air Canada & Danier Leather \\
\hline Akita Drilling & DHX Media \\
\hline Alignvest Acquisition Corp & Dorel Industries \\
\hline Alimentation Couche-Tard & Dream Unlimited \\
\hline Andrew Peller & Dundee Acquisition Ltd \\
\hline ATCO & Dundee Corp \\
\hline Becker Milk & Empire Company \\
\hline Bombardier & Exfo \\
\hline Brampton Brick & Fairfax Financial Holdings Ltd \\
\hline Brookfield Asset Management & Fairfax India Holdings Corp \\
\hline Brookfield Real Estate Services & Fiera Capital Corp \\
\hline $\begin{array}{l}\text { Brookfield Renewable Energy Partners } \\
\text { LP }\end{array}$ & FirstService Corp \\
\hline BRP Inc & GDI Integrated Facility Services \\
\hline Can-Financials Income Corp & Gibraltar Growth Corp \\
\hline Canadian Tire & Guardian Capital Group Ltd \\
\hline Canadian Utilities & GVIC Communications \\
\hline Cara Operations & Hammond Manufacturing \\
\hline Cargojet Inc & Hammond Power Solutions \\
\hline CCL Industries & HNZ Group \\
\hline Celestica & INFOR Acquisition Corp \\
\hline Central Fund of Canada & Information Services Corp \\
\hline CGI Group & INSCAPE Corp \\
\hline Chorus Aviation & Jean Coutu Group \\
\hline Cogeco & Lassonde Industries \\
\hline Cogeco Communications & Le Chateau Inc. \\
\hline Colliers International & Logistec Corp \\
\hline
\end{tabular}

Madison Pacific Properties

MDC Partners

Molson Coors Canada

Newfoundland Capital Corp

Onex

Ovivo Inc

Postmedia Network Canada Corp

Power Corporation of Canada

Quebecor Inc

Reitmans

Rogers Communications

Shaw Communications

Shopify Inc

Sirius XM Canada Holdings

Smart Real Estate Investment Trust

Spin Master Corp

Stingray Digital Group

Teck Resources Ltd

Torstar Corp

Transat A.T. Inc

Transcontinental

Trimetals Mining

TVA Group

Urbana Corp

Velan Inc

Westjet Airlines

Wilmington Capital Management 
Appendix 3

Description of Governance Characteristics

\begin{tabular}{|c|c|}
\hline Criteria/Variables & Description \\
\hline \multicolumn{2}{|l|}{ Governance Characteristics } \\
\hline $\begin{array}{l}\text { Governance Characteristic 1: Majority of the } \\
\text { Minority Vote }\end{array}$ & $\begin{array}{l}\text { Each firm was examined to determine whether } \\
\text { subordinate shareholders have the ability to vote } \\
\text { on matters such as the way in which control is } \\
\text { held via a majority of the minority vote process. } \\
\text { It was determined whether a majority of the } \\
\text { subordinate shareholders' vote is required for } \\
\text { any items, except if the company dissolves or if } \\
\text { required by law, and was sorted into the } \\
\text { following categories: election of directors, } \\
\text { appointment of auditors, approval of financial } \\
\text { statements, and other. } \\
\text { Source: SEDAR }\end{array}$ \\
\hline $\begin{array}{llll}\text { Governance } & \text { Characteristic } & \text { 2: } & \text { Sunset } \\
\text { Provision } & & & \end{array}$ & $\begin{array}{l}\text { Each firm was examined to determine whether it } \\
\text { is subject to a sunset provision limiting the length } \\
\text { that the DCS will exist in the corporation. Sunset } \\
\text { clause provisions are sorted into the following } \\
\text { categories: voting rights, employment, qualifying } \\
\text { acquisition, foreign ownership, and other. } \\
\text { Source: SEDAR }\end{array}$ \\
\hline $\begin{array}{l}\text { Governance Characteristic 3: Independent } \\
\text { Directors }\end{array}$ & $\begin{array}{l}\text { Each firm was examined to determine whether } \\
\text { its board is populated by more independent } \\
\text { directors than is recommended by law } \\
\text { (majority). It was determined whether the board } \\
\text { has a majority of independent directors, an even } \\
\text { number of independent and non-independent } \\
\text { directors, or majority of non-independent } \\
\text { directors in } 2015 \text {. } \\
\text { Source: SEDAR }\end{array}$ \\
\hline Percentage of Board Independence & $\begin{array}{l}\text { For each firm, a percentage of board } \\
\text { independence was calculated by dividing the } \\
\text { number of independent board members by the } \\
\text { total number of board members. }\end{array}$ \\
\hline
\end{tabular}




\begin{tabular}{|c|c|}
\hline & Source: SEDAR \\
\hline $\begin{array}{l}\text { Governance Characteristic 4: Independent } \\
\text { Chair }\end{array}$ & $\begin{array}{l}\text { Each firm was examined to determine whether } \\
\text { the board of the DCS corporation is led by an } \\
\text { independent board chair. Independence was } \\
\text { determined based on the definition set out in } \\
\text { National Instrument } 52-110 \text { Audit Committees } \\
\text { and as referred to by National Instrument 58-101 } \\
\text { Disclosure of Corporate Governance Practices. } \\
\text { Source: SEDAR, Standard \& Poor's Capital IQ }\end{array}$ \\
\hline Lead Independent Director & $\begin{array}{l}\text { Each firm was examined to determine whether it } \\
\text { appointed a lead independent director on the } \\
\text { board. } \\
\text { A lead independent director is typically } \\
\text { appointed to chair meetings of independent } \\
\text { directors and help provide oversight of the } \\
\text { board. } \\
\text { Source: SEDAR }\end{array}$ \\
\hline $\begin{array}{l}\text { Chair of the Board is Uninvolved with } \\
\text { Management }\end{array}$ & $\begin{array}{l}\text { Each firm was examined to determine whether } \\
\text { its chair of the board of directors is or is not } \\
\text { involved in management of the company. } \\
\text { Source: SEDAR }\end{array}$ \\
\hline $\begin{array}{l}\text { Governance Characteristic 5: Change of } \\
\text { Control Provisions }\end{array}$ & $\begin{array}{l}\text { Each firm was examined to determine whether } \\
\text { the corporate charter contains provisions } \\
\text { specifying change of control rights for the } \\
\text { subordinate shareholders in addition to the } \\
\text { mandatory TSX coattail provision. } \\
\text { Source: SEDAR }\end{array}$ \\
\hline
\end{tabular}

\section{APPENDIX 4}

\section{Background on DCS Firms where the DCS is de facto required:}

RBL firms use the different voting share classes to strategically ensure a minimum level of Canadian ownership is maintained in accordance with applicable legislation, such as the Canada Transportation Act. ${ }^{153}$ These firms stipulate provisions by which shares are automatically

${ }^{153}$ Canada Transportation Act, SC 1996, c 10. 
converted between classes depending on whether the shareholder is Canadian or not. They further stipulate provisions which limit the voting power of the non-Canadians such that the total voting rights held by non-Canadians do not exceed the limit as per legislation.

Air Canada, for example, utilizes an automatic share conversion policy which ensures Class B shares are only held by Canadians and Class A shares are only held by non-Canadians. In the case that a Class B share is held by a non-Canadian, it is automatically converted into a Class A share. Similarly, in the case that a Class A share is held by a Canadian, it is automatically converted into a Class B share. In addition to the automatic conversion, Air Canada stipulates that should the number of Class A shares exceed 25 percent of the total shares or should the total votes cast by Class A shares exceed 25 percent of the total votes at a meeting, the votes attached to each Class A share will be decreased proportionately such that all Class A shares do not hold more than 25 percent of the total votes and do not exceed 25 percent of the total votes cast at a meeting. ${ }^{154}$ This provision ensures that at no point in time will Class A shares hold more than 25 percent of the voting power or more than 25 percent of the total votes at any given meeting.

Cargojet Inc., Chorus Aviation, Transat A.T. Inc., and Westjet Airlines have implemented similar provisions and DCS structures in order to abide by the Canada Transportation Act, which mandates that at least 75 percent of the voting interests of the company be owned and controlled by Canadians in order to classify a Canadian airline. ${ }^{155}$ The Broadcasting Act ${ }^{156}$ similarly imposes foreign ownership restrictions which have prompted some firms to implement DCS structures. Chorus Entertainment and DHX Media, for example, utilize a DCS to ensure nonCanadian ownership does not surpass 33.33 percent of the voting shares or votes at a meeting. ${ }^{157}$

\footnotetext{
${ }^{154}$ Air Canada, Management Information Circular (April 2016), online: <http://www.sedar.com>.

155 Section 55(1), Canada Transportation Act, SC 1996, c 10.

${ }^{156}$ Broadcasting Act, SC 1991, c 11.

${ }^{157}$ See: Chorus Entertainment, Annual Information Form (Nov 2015), online: <http://www.sedar.com>; DHX Media, Management Information Circular (Nov 2015), online: < http://www.sedar.com>.
} 


\section{Background on Change of Control Provisions in DCS implemented via Trust Agreements}

Ten firms firms that had trust agreements in place to ensure that equivalent terms are offered to subordinate shareholders in the case of take-overs (though none of them were income trusts per se). These ten firms have explicit agreements made with the founders or majority shareholders and a trustee, stipulating that certain actions (e.g. the transfer of shares prior to the completion of a qualifying acquisition) require authorization by the trustee who acts on behalf of the holders of the SVS. Of these firms, five firms have founders who have agreed not to transfer their shares prior to the completion of a qualifying acquisition and the other five have varying other provisions. These provisions as summarized as follows:

- ADF Group stipulates that prior written consent of the Trustee shall be required in connection with any direct or indirect sale or disposition of MVS by the Principal Shareholders.

- Danier Leather has a trust agreement that stipulates that MVS will be converted if transferred to non-permitted person (note that this overlaps with their sunset clause).

- DHX Media has an agreement that the founder will not transfer their preferred voting shares without prior board approval.

- Sirius XM Canada Holdings sets out that it cannot issue Class A shares to Class C or Class B holders through conversion rights if it would cause the restricted class to hold greater than 33 $1 / 3$ percent of the voting rights or voting shares.

- Fairfax Financial specifically agreed not sell its MVS holdings unless an equal offer is made to SVS.

- Newfoundland Capital's trust agreement outlines that the majority shareholder agrees not to accept any take-over bid unless a similar offer is also made to Class $A$.

- Onex set out that the transfer of MVS requires two-third approval through a separate class vote.

- Air Canada set out that under its amended Rights Plan, each right, other than those held by an Acquiring Person and certain of its related parties, entitles the holder to purchase from Air Canada $\$ 200$ worth of Variable Voting Shares or Voting Shares for $\$ 100$ (i.e. at a 50 percent 
discount) in certain circumstances following an offer to acquire 20 percent or more of the outstanding Variable Voting Shares and Voting Shares of Air Canada calculated on a combined basis.

- Cymbria's trust agreement sets out that Common Shares cannot be disposed until all Class A \& Class J shares are retracted.

- Fiera Capital has several agreements regarding the transfer of shares and voting (specifically DFH, National Bank, DJM, Arvestia Inc., Fiera Capital Inc. and Fiera L.P. entered into a principal investors agreement and a voting arrangements/put option agreement was entered into between Jean-Guy Desjardins and National Bank). 


\section{References}

Adams, R. and D. Ferreira (2007) "A Theory of Friendly Boards", 62 Journal of Finance 217.

Allaire, Y. (27 May 2015) "In Praise of Dual-Class Shares" Financial Post, online: < business.financialpost.com/fp-comment/in-praise-of-dual-class-of-shares>.

Allaire, Y. (2010) “Controlled Companies Briefing" Canadian Institute of Chartered Accountants, online: < https://www.cpacanada.ca/-/media/site/business-and-accountingresources/docs/controlled-companies-briefing---questions-for-directors-to-ask.pdf>.

Amaoko-Adu, B, B. Smith, and V. Baulkaran (15 February 2011), "Unification of Dual-class Shares in Canada with Clinical Case on Magna International" (Paper delivered at the Capital Markets Institute Conference on Dual-class Shares, Rotman School of Management, University of Toronto) [unpublished], online:

<http://www.rotman.utoronto.ca/userfiles/cmi/file/Magna\%20Unif2_Feb\%207\%20(Revised ).pdf>.

Amoako-Adu, B. and B. F. Smith (2001) 'Dual Class Firms: Capitalization, Ownership Structure and Recapitalization Back into Single Class' 25 Journal of Banking and Finance 1083.

Anand, A. (22 February 2016) "The success stories of dual-class shares miss an incontrovertible truth", The Globe and Mail, online: < https://beta.theglobeandmail.com/report-onbusiness/rob-commentary/the-success-stories-of-dual-class-stocks-miss-an-incontrovertibletruth/article28830388/?ref=http://www.theglobeandmail.com\&>.

Anand, A. (2016) 'Offloading the Burden of Being Public: An Analysis of Multi-Voting Share Structures' 10 Virginia Law \& Business Review.

Anand, A. (2012) 'Was Magna in the Public Interest?' 49 Osgoode Hall Law Journal 311.

Anand, A. (2006) 'An Analysis of Enabling vs Mandatory Corporate Governance: Structures PostSarbanes-Oxley' 31 Delaware Journal of Corporate Law 229.

Anand, A., F. Milne and L. Purda (2012) 'Domestic and International Influences on Firm-level governance: Evidence from Canada' 14 American Law and Economics Review 68.

Anand, A., F. Milne and L. Purda (2010) 'Monitoring to Reduce Agency Costs: Examining the Behavior of Independent and Non-Independent Boards' 33 Seattle University of Law Review 809.

Anderson, D., S. Melanson and J. Maly (2007) 'The Evolution of Corporate Governance: Power Redistribution Brings Boards to Life' 15 Corporate Governance: An International Review 780. 
Anderson, R., E. Ottolenghi and D. Reeb (2017) The Dual Class Premium: A Family Affair, Fox School of Business Research Paper No.17-021.

Arrunada, B. and C. Paz-Ares (1995) 'The Conversion of Ordinary Shares into Nonvoting Shares', 15:4 International Review of Law and Economics 351.

Arugaslan, O., D. O. Cook and R. Kieschnick (2010) 'On the Decision to go Public with Dual Class Stock' 16 Journal of Corporate Finance 170.

Bainbridge, S. (15 November 2015) “What To Do About Dual Class Stock (If Anything)?” Stephen Bainbridge's Journal of Law, Politics, and Culture, online: < http://www.professorbainbridge.com/professorbainbridgecom/2015/11/what-to-do-aboutdual-class-stock-if-anything.htm $>$.

Baran, L., A. Forst, and M. Via (2017), Dual Class Firm Structure and Innovation, Financial Management Association (working paper), online: <http://fmaconferences.org/Boston/DualClassInnovationFMA.pdf>.

Bebchuk, L., R. Kraakman, and G. Triantis (1999), Stock Pyramids, Cross-Ownership and Dual Class Equity: The Mechanisms and Agency Costs of Separating Control From Cash-Flow Rights, National Bureau of Economic Research Working Paper No. 6951., online: < https://papers.ssrn.com/sol3/papers.cfm?abstract_id=147590>.

Bebchuk, L. A. and K. Kastiel (2017) 'The Untenable Case for Perpetual Dual-Class Stock', 103 Virginia Law Review 585.

Ben-Amar, W. and P. Andre (2006) 'Separation of Ownership from Control and Acquiring Firm Performance: The Case of Family Ownership in Canada' 33 Journal of Business, Finance, and Accounting 517.

Ben-Ishai, S. and P. Puri (2006) ‘Dual Class Shares in Canada: An Historical Analysis' 29 Dalhousie Law Journal 117.

Bergstrom, C. and K. Rydqvist (1990) 'Ownership of Equity in Dual-Class Firms' 14 Journal of Banking and Finance 255.

Berle, A. and G. Means (1933), The Modern Corporation and Private Property (MacMillan, rev edn 1967).

Bertsch, K. (9 March 2017) "Unequal Voting rights in Common Stock" (CII Remarks to Investor Advisory Committee Council of Institutional Investors delivered at the U.S. Securities and exchange Commission) [unpublished]. 
Black, B., H. Jang, and W. Kim (2005) Does Corporate Governance Predict Firms' Market Values? Evidence from Korea, European Corporate Governance Institute Working Paper No 86/2005.

Black, B. (2001) 'The Corporate Governance Behaviour and Market Value of Russian Firms' 2 Emerging Market Review 89.

Brennan, N. and M. McDermott (2004) 'Alternative Perspectives on Independence of Directors' 12 Corporate Governance: An International Review 325.

Chemmanur, T. and Y. Jian (2012) 'Dual Class IPOs: A Theoretical Analysis' 36 Corporate Journal of Banking and Finance 306.

Chhaochharia, V. and Y. Grinstein (2007) 'The Changing Board of Directors: Board Independence in S\&P 500 Firms' 11 Corporate Governance: An International Review 1215.

Costaldo, J. (10 February 2017) “Dual Class Shares are in fashion again - but they're still a bad idea" Canadian Business, online: < http://www.canadianbusiness.com/investing/dual-classshares-are-in-fashion-again-but-theyre-still-a-bad-idea>.

Council of Institutional Investors. (27 April 2017) "In re: S\&P Dow Jones Indices consultation with members of the investment community on the eligibility of non-voting share classes in S\&P DJI indices" Financial Post, online: < http://www.cii.org/files/issues_and_advocacy/correspondence/2017/20170426 percent20CII percent20comment percent20S\&P percent20no percent20vote percent20share.pdf>.

Critchley, B. (14 May 2015) "Time for regulators to take major look at DCS" Financial Post, online: < business.financialpost.com/news/fp-street/time-for-regulators-to-take-major-lookat-dual-class-shares/wcm/7b02fd1c-d28a-422c-ba39-aac77a1b6bb7>.

Cronqvist, H. and M. Nilsson (2003) 'Agency Costs of Controlling Minority Shareholders' 38 Journal of Financial and Quantitative Analysis 695.

Dahya, J., O. Dimitrov, and J. McConnell (2008) 'Dominant Shareholders, Corporate Boards and Corporate Value: A Cross-Country Analysis' 87 Journal of Financial Economics 73.

Daines, R. and M. Klausner (2001) 'Do IPO Charters Maximize Firm Value? Antitakeover Protection in IPOs' 17 Journal of Law, Economics and Organization 83.

Deal Professor. (3 February 2017) "Snap's Plan is Most Unfriendly to Outsiders" The New York Times, online: <https://www.nytimes.com/2017/02/03/business/dealbook/snap-ipo-planevan-spiegel.htm>. 
DeAngelo, H. and L. DeAngelo (1985) 'Managerial Ownership of Voting Rights: A Study of Public Corporations with Dual Classes of Common Stock' 14 Journal of Financial Economics 33.

Der Marderosian, L. (25 May 2017) "2017 IPO Report” Harvard Law School Forum on Corporate Governance and Financial Regulation (blog), online: <https://corpgov.law.harvard.edu/2017/05/25/2017-ipo-report/>.

Dimitrov, V. and P. C. Jain (2006) 'Recapitalization of One Class of Common Stock into DualClass: Growth and Long-Run Stock Returns' 12 Journal of Corporate Finance 342.

Dyck, A. and L. Zingales (2004) ‘Private Benefits of Control’ 59 Journal of Finance 593.

Economist, The. (22 September 2014) "Out of Control" The Economist, online: < https://www.economist.com/news/finance-and-economics/21618889-more-worlds-bigstockmarkets-are-allowing-firms-alibaba-sideline>.

Feldman, S. G. (7 April 2016) "BNA Insights: IPOs in 2016 increasingly include Dual-Class Shareholder Voting Rights", Bloomberg BNA, online: < www.olshanlaw.com/media/publication/362_Feldman percent20BNA percent20Dual-Class percent20Article.pdf>.

Fenton. T. A (2016) "Here to stay - Dual Class Share Structures" The Canadian Institute's Securities Law \& Litigation, online: $<$ www.airdberlis.com/Templates/Articles/binaryServer.ashx?bin=1000721.pdf>.

Ferreira, D. and R. Adams (2008) ‘One Share-One Vote: The Empirical Evidence’ 14 Review of Finance 51.

Financier Worldwide (September 2014) "The Role of the Lead Director" Financier Worldwide, online: <https://www.financierworldwide.com/the-role-of-the-lead-director/\#.WaQeRLGZN$U>$.

Finegold, D., G. S. Benson, and D. Hecht (2007) 'Corporate Boards and Company Performance: Review of Research in Light of Recent Reforms' 15 Corporate Governance: An International Review 865.

Fortune. (1 August 2017) "Incentives vs. Control: An Analysis of U.S. Dual-Class Companies", Fortune, online: < fortune.com/2017/08/01/snap-snapchat-stock-shares-sp-500/>.

Gilbert, M. B., P. Olasker, et al. (31 July 2017) “Boards Beware: Regulators Actively Monitoring Related Party Transactions" Davies LLP, online: < https://www.dwpv.com/en/Insights/Publications/2017/Boards-Beware-Regulators-ActivelyMonitoring-Related-Party-Transactions>. 
Gompers, P.A., J. Ishii, and A. Metrick (2004) Incentives vs. Control: An Analysis of U.S. DualClass Companies, National Bureau of Economic Research Working Paper No. 10240.

Goshen, Z. and R. Squire (2017) 'Principal Costs: A New Theory for Corporate Law and Governance', 117 Columbia Law Review 767.

Goshen, Z. and A. Hamdani (2016) 'Corporate Control and Idiosyncratic Vision', 125 Yale Law Journal 560.

Harris, M. and A. Raviv (1988) 'Corporate Governance: Voting Rights and Majority Rules' 20 Journal of Financial Economics 203.

Hasselback, D. and B. Shecter. (5 May 2015) "From Cara Operations Itd to Shopify Inc: Why DCS are suddenly cool again" Financial Post, online: < business.financialpost.com/news/fpstreet/from-cara-to-google-why-dual-class-shares-are-suddenly-cool-again>.

Hill, A. (18 July 2011) "Enrolment Open for an MBA in Murdoch", Financial Times, online: < http://www.ft.com/cms/s/0/2fda9e8e-b176-11e0-9444-

00144feab49a.html\#axzz2IYIKmzDt>.

Hossain, A. (2014) 'Dual v. Single Class Firms: An Acquisition Perspective' 14 Journal of Accounting and Finance 1221.

Hu, H. and B. Black (2008) 'Equity and Debt Decoupling and Empty Voting II: Importance and Extensions' 156 University of Pennsylvania Law Review 625.

Humphery-Jenner, M. (2014) 'Takeover Defenses, Innovation, and Value Creation: Evidence from Acquisition Decision' 35 Strategic Management Journal 668.

lacobucci, E. (2011) ‘Making Sense of Magna' 49:2 Osgoode Hall Law Review 237.

Iliev, P., K. V. Lins, et al. (2015) 'Shareholder Voting and Corporate Governance Around the World' 28 The Review of Financial Studies 2167.

Jackling, B. and S. Johl (2009) 'Board Structure and Firm Performance: Evidence from India's Top Companies' 17 Corporate Governance: An International Review 492.

Jensen, M. and W. Meckling (1976) 'Theory of the Firm: Managerial Behavior, Agency Costs and Ownership Structure' 3 Journal of Financial Economics 305.

Jog, V.M., S. Dutta, and P. C. Zhu (2010) 'Impact of Restricted Voting Share Structure on Firm Value and Performance' 18 Corporate Governance: An International Review 415. 
Jordan, B., S. Kim and M. H. Liu (2016) 'Growth Opportunities, Short-Term Market Pressure, and Dual-Class Share Structure' 41 Journal of Corporate Finance 304.

Khalil, S. and M. Magnan (2007) 'Dual-Class Shares: Governance, Risk and Rewards' Ivey Business Journal Online, online: <http://iveybusinessjournal.com/publication/dual-classshares-governance-risks-and-rewards/>.

Kiladze, T. (22 February 2011) 'Magna board 'spectacularly' vacated field: judge' The Globe and Mail, online: < http://www.theglobeandmail.com/globe-investor/investmentideas/streetwise/magna-board-spectacularly-vacated-field-judge/article1916419>.

King, M.R. and E. Santor (2008) 'Family Values: Ownership Structure, Performance and Capital Structure of Canadian Firms' 32 Journal of Banking and Finance 2423.

Kirby, J. (2 August 2016) 'Public companies in Canada are going the way of the Dodo' Maclean's, online: < www.macleans.ca/economy/economicanalysis/public-companies-in-canada-aregoing-the-way-of-the-dodo/>.

Lee, I. B. (8 November 2005) "There is a Logic in Dual-Class Shares" National Post, online: < https://www.law.utoronto.ca/documents/lee/DualClassOpEd.pdf>.

Lee, S. and L. Carlson (2007) 'The Changing Board of Directors: Board Independence in S\&P 500 Firms' 11 Journal of Organizational Culture, Communication, and Conflict 31.

Li, T. and N. Zaiata (2017) 'Information Environment and Earning Management of Dual Class Firms Around the World' 74 Journal of Banking and Finance.

Licht, A. (2018) Be Careful What You Wish For: How Progress Engendered Regression in Related Party Transaction Regulation in Israel, European Corporate Governance Institute (ECGI) Working Paper No 382, online: <https://papers.ssrn.com/sol3/papers.cfm?abstract_id=3104062>.

Lin, Y. H. (2017) “Controlling Controlling-minority shareholders: Corporate Governance and Leveraged Corporate Control" 2 Columbia Business Law Review 453.

Loureiro, G. (2012) 'Monitoring the Board: Should Shareholders have Direct Proxy Access?' 12 Quantitative Analysis 943.

Market Intelligence Group. (December 2015) “MiG Report December 2015” Toronto Stock Exchange, online: < https://www.tsx.com/resource/en/1265/mi-g-report-december-2015en.pdf>. 
Marowitz, R. (9 May 2017), "Ontario Teacher's Pension Plan votes against Bombardier chair", The Toronto Star, online: <https://www.thestar.com/business/2017/05/09/ontario-teacherspension-plan-votes-against-bombardier-chair.html>.

Masulis, R. W., C. Wang and F. Xie (2009) 'Agency Problems at Dual-class Companies' 64 Journal of Finance 1697.

McCahery, J. A. and E. P. M. Vermeulen (2016) "Venture Capital 2.0: From Venturing to Partnering" 1 Annals of Corporate Governance 95.

Merkley, M. (9 February 2015) "Multiple Voting Shares: Don't Call It a Comeback" Blake, Cassels \& Graydon LLP, online: < http://www.blakes.com/English/Resources/TrendsInsights/Pages /details.aspx?AnnouncementID=78>.

Morey, G. (May 2017) “Multi-Class Stock and Firm Value” Council of Institutional Investors, online: <http://www.cii.org/files/publications/misc/05_10_17_dual-class_value_study.pdf>.

Nicholas, B. and B. Marsh (17 May 2017) “Dual-Class: The Consequences of Depriving Institutional Investors of Corporate Voting Rights" Harvard Law School Forum on Corporate Governance and Financial Regulation (blog), online: < https://corpgov.law.harvard.edu/2017/05/17/dual-class-the-consequences-of-deprivinginstitutional-investors-of-corporate-voting-rights $>$.

Nuesch, S. (2016) 'Dual-Class Shares, External Financing Needs, and Firm Performance' 20 Journal of Management and Governance 525.

Partch, M. M. (1987) 'The Creation of a Class of Limited Voting Common Stock and Shareholder Wealth' Journal of Financial Economics 313.

Rock, E. (2018) MOM Approval in a World of Activity Investors, NYU Law School Working Paper No. 18-02, online: <https://ssrn.com/abstract=3122681>.

Sauerwald, S., Van Oosterhout, J. and M. Van Essen (2016) 'Expressive Shareholder Democracy: A Multilevel Study of Shareholder Dissent in 15 Western European Countries' 53 Journal of Management Studies 520.

Shareholder Association for Research and Education (April 2004) "Second Class Investors: The use and abuse of subordinate shares in Canada", Shareholder Association for Research and Education online: < http://www.share.ca/files/Second_Class_Investors.pdf>.

Sharfman, B. S. (2017) 'A Private Ordering Defence of a Company's Right to use Dual Class Share Structures in IPOs' 63 Villanova Law Review 1 (Forthcoming). 
Sharfman, B. S. (1 August 2017) "How DCS in IPOs Can Create Value" Columbia Law School's Blog on Corporations and the Capital Markets, online: < http://clsbluesky.law.columbia.edu/2017/08/01/how-dual-class-shares-in-ipos-can-createvalue>.

Shen, J. (4 November 2016) "A Comparative Analysis of Dual Class Share Structures" Columbia Law School's Blog on Corporations and the Capital Markets, online: < http://clsbluesky.law.columbia.edu/2016/11/04/a-comparative-analysis-of-dual-class-sharestructures/>.

Shleifer, A. and R.W. Vishny (1986) 'Large Shareholders and Corporate Control' 94 Journal of Political Economy 461.

Smart, S., R.S. Thirumalai and C.J. Zutter (2008) 'What's in a Vote? The Short and Long-Run Impact of Dual-Class Equity on IPO firm Values' 45 Journal of Accounting and Economics 94.

Smart, S.B. and C.J. Zutter (2003) 'Control as a Motivation for Underpricing: A Comparison of Dual-and Single-Class IPOs' 69 Journal of Financial Economics.

Solomon, D. (4 November 2015) "Shareholders Vote with Their Dollars to Have Less of a Say" New York Times, online: <https://www.nytimes.com/2015/11/05/business/dealbook/shareholders-vote-with-theirdollars-to-have-less-of-a-say.html $>$.

Spencer Stuart. (2016) "Canadian Spencer Stuart Board Index 2016 Board Trends and Practices of Leading Canadian Companies" Spencer Stuart, online: < https://www.spencerstuart.com/ /media/pdf\%20files/research\%20and\%20insight\%20 pdfs/\%20spencer-stuart-canadian-board-index-dec-2016.pdf >.

Spizzirri, A. and M. Fullbrook (2013) "The Impact of Family Control on the Share Price Performance of Large Canadian Publicly-Listed Firms (1998-2012)" Clarkson Centre for Board Effectiveness, online: <http://www.rotman.utoronto.ca/-/media/Files/Programs-andAreas/CCBE/FamilyFirmPerformanceReport1993-2012-Sep2013update.pdf>.

Surowiecki, J. (18 May 2012) "Unequal Shares" The New Yorker, online: < www.newyorker.com/magazine/2012/05/28/unequal-shares>.

Toronto Stock Exchange. (31 December 2015) "Listing With Us" Toronto Stock Exchange, online: $<$ https://www.tsx.com/listings/listing-with-us>.

Toronto Stock Exchange. (1994) "Where Were The Directors? Guidelines for Improved Corporate Governance in Canada". 
Torys LLP. (19 July 2017) "Canadian IPOs on the Rebound in 2017" Torys LLP, online: < https://www.torys.com/insights/publications/2017/07/canadian-ipos-on-the-rebound-in2017>.

Tsipouri, L., and M. Xanthakis (2004) 'Can Corporate Governance Be Rated? Ideas Based on the Greek Experience' 12 Corporate Governance: An International Review 16.

Valsan, C. (2007) “A Canadian Corporate Ownership Survey” Bishop's University - William School of Business, online:

<https://papers.ssrn.com/sol3/papers.cfm?abstract_id=1158544>.

Vecchialla, R., M. Prudom, and R. Hamilton III (1998) ' Exposing the Corporate Vampires: A Shareholder's Guide to Management Entrenchment' 31 Long Range Planning 659.

Wang, C., Xie, F. and M. Zhu (2015) 'A Industry Expertise of Independent Directors and Board Monitoring' 50 Journal of Financial and Quantitative Analysis 929.

Wen, T. (2014) 'You Can't Sell Your Firm and Own it Too: Disallowing Dual-Class Stock Companies from Listing on Securities Exchanges' 162 University of Pennsylvania Law Review 1495.

Willis, A. (5 August 2005) "Dual Class share structure should end, Caldwell Told" The Globe and Mail, online: < https://www.theglobeandmail.com/report-on-business/dual-class-sharestructure-should-end-caldwell-told/article18243209>.

Winden, A. W. (2017) Sunrise, Sunset: An Empirical and Theoretical Assessment of Dual-Class Stock Structures, Rock Center for Corporate Governance at Stanford University Working Paper No. 228.

Wong, S. C. Y. (29 January 2013), "Rethinking One Share, One Vote", Harvard Business Review, online: < https://hbr.org/2013/01/rethinking-one-share-one-vote>.

Woods, A. (11 May 2017), "Bombardier's Pierre Beaudoin gives up executive title, but will continue to lead board", Toronto Star, online:

<https://www.thestar.com/news/canada/2017/05/11/bombardiers-pierre-beaudoinstepping-down-as-executive-chair.html>. 